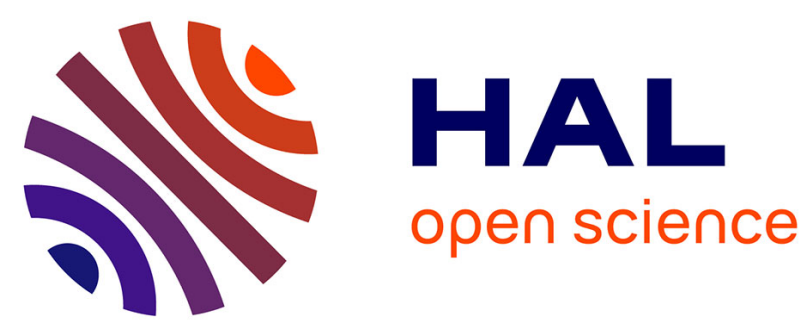

\title{
Southern Ocean influence on the eastern tropical North Pacific's intermediate-depth circulation during the Last Glacial Maximum
}

\author{
José D Carriquiry, Alberto Sanchez, Guillaume Leduc
}

\section{- To cite this version: \\ José D Carriquiry, Alberto Sanchez, Guillaume Leduc. Southern Ocean influence on the eastern tropical North Pacific's intermediate-depth circulation during the Last Glacial Maximum. Paleo- ceanography, 2015, 30, pp.1132 - 1151. 10.1002/2014PA002766 . hal-01457239}

\section{HAL Id: hal-01457239 \\ https://hal-amu.archives-ouvertes.fr/hal-01457239}

Submitted on 6 Feb 2017

HAL is a multi-disciplinary open access archive for the deposit and dissemination of scientific research documents, whether they are published or not. The documents may come from teaching and research institutions in France or abroad, or from public or private research centers.
L'archive ouverte pluridisciplinaire HAL, est destinée au dépôt et à la diffusion de documents scientifiques de niveau recherche, publiés ou non, émanant des établissements d'enseignement et de recherche français ou étrangers, des laboratoires publics ou privés. 


\section{Paleoceanography}

\author{
RESEARCH ARTICLE \\ 10.1002/2014PA002766 \\ Key Points: \\ - $\delta^{13} \mathrm{C}$ data refine glacial Pacific water \\ mass geometry at intermediate depth \\ - California Margin was the terminus of \\ LGM circulation \\ - Comparison of $\delta^{13} \mathrm{C}$ profiles suggests \\ greater contribution of Antarctic waters
}

Correspondence to:

J. D. Carriquiry,

carriquiry@uabc.edu.mx

\section{Citation:}

Carriquiry, J. D., A. Sanchez, and

G. Leduc (2015), Southern Ocean

influence on the eastern tropical North

Pacific's intermediate-depth circulation

during the Last Glacial Maximum,

Paleoceanography, 30, doi:10.1002/

2014 PA002766.

Received 8 DEC 2014

Accepted 15 JUL 2015

Accepted article online 16 JUL 2015

\section{Southern Ocean influence on the eastern tropical North Pacific's intermediate-depth circulation during the Last Glacial Maximum}

\author{
José D. Carriquiry', Alberto Sanchez ${ }^{1,2}$, and Guillaume Leduc ${ }^{3}$ \\ ${ }^{1}$ Instituto de Investigaciones Oceanológicas, Universidad Autónoma de Baja California, Ensenada, Mexico, ${ }^{2}$ Now at Centro \\ Interdisciplinario de Ciencias Marinas, Instituto Politécnico Nacional, La Paz, Mexico, ${ }^{3}$ CEREGE UM34, Aix-Marseille \\ Université, CNRS, Europôle Méditerranéen de L'Arbois, Aix en Provence, France
}

Abstract The oxygen and carbon isotopic compositions of benthic foraminiferal tests were measured on sedimentary sequences retrieved on the Magdalena Margin, off southern Baja California, Mexico. We reconstruct the hydrographic changes along the water column that occurred in the northeastern tropical Pacific since the Last Glacial Maximum (LGM) and compare those changes to the ones that occurred in the northwest Pacific (NWP, i.e., off Japan and Russia), in the northeast Pacific along the Californian Margin, as well as in the southeast Pacific (off Chile). The foraminiferal $\delta^{18} \mathrm{O}$ depth profiles across the North and southeast Pacific show similar trends between the LGM and the Holocene, indicating that changes in the oceanographic conditions between $\sim 400$ and $2000 \mathrm{~m}$ depth were very similar. Changes in the isotopic composition of dissolved inorganic carbon $\left(\delta^{13} \mathrm{C}_{\mathrm{DIC}}\right)$ in the Baja California Margin since the Last Glacial Maximum were reconstructed using the $\delta^{13} \mathrm{C}$ of shallow endobenthic foraminifers $U$. peregrina and the epibenthic Cibicides mckannai. The most striking result is a marked shift toward more positive $\delta^{13} \mathrm{C}$ values below $1200 \mathrm{~m}$ depth in the northeast Pacific (NEP) during the Holocene (relative to the LGM). This observation suggests that a nutrient-rich water mass ventilated the NEP during the LGM. At a basin scale, the $\delta^{13} \mathrm{C}$ values of NEP waters at intermediate depths were more negative relative to the NWP and southeast Pacific during the LGM, suggesting that the nutrient-rich water column along the NEP (i.e., Baja California Margin) was confined in that area as observed today.

\section{Introduction}

The dramatic decrease of atmospheric radiocarbon content that occurred during the last deglaciation led paleoceanographers to suggest that a large volume of abyssal waters remained isolated from the sea surface for millennia until the end of the Last Glacial Maximum (LGM) [Denton et al., 2006]. The ventilation of these abyssal waters, that likely occurred in tandem with other climatic and oceanographic processes [Broecker, 2009; Hain et al., 2014], had a massive impact on the distribution of oxygen and nutrients on the global ocean [Jaccard and Galbraith, 2012]. The Pacific is the largest potential abyssal reservoir for glacial nutrient-rich, radiocarbon, and oxygen-depleted waters. Several studies have reported episodes of deepwater formation in the North Pacific during the deglaciation [see, e.g., Duplessy et al., 1988; Lynch-Stieglitz and Fairbanks, 1994; Okazaki et al., 2010; Rae et al., 2014], suggesting that large reorganizations of intermediate and deepwater masses occurred between the LGM and the Holocene, in association with a transfer of nutrients from the abyss to the upper $2 \mathrm{~km}$ of the Pacific Ocean [Jaccard and Galbraith, 2012].

Unlike the modern deep Pacific that is relatively chemically uniform, the upper $2000 \mathrm{~m}$ host different water masses, some of which are being impacted by dysoxia and anoxia (Figure 1). In the modern ocean, the oldest waters are found at $2000 \mathrm{~m}$ depth in the North Pacific, north of $20^{\circ} \mathrm{N}$ [Matsumoto, 2007; Galbraith et al., 2007]. These oldest waters are situated just underneath oxygen-depleted, nutrient-rich waters that bath the entire North Pacific at 1000 to $1500 \mathrm{~m}$ water depth [Kroopnick, 1985; Helly and Levin, 2004] (Figure 1). While poor ocean ventilation of high-latitude sourced water mass is mainly responsible for oxygen depletion at those depths in the North Pacific, high primary productivity along the eastern tropical Pacific largely contributes to the anoxic conditions found along the northwestern America margin in the so-called oxygen minimum zone (OMZ) [Helly and Levin, 2004; van Geen et al., 2003; Ortiz et al., 2004; Cartapanis et al., 2011]. Such modern oxygen distribution in the Pacific Ocean is faithfully mirrored in the distribution of dissolved

(C)2015. American Geophysical Union. All Rights Reserved. 


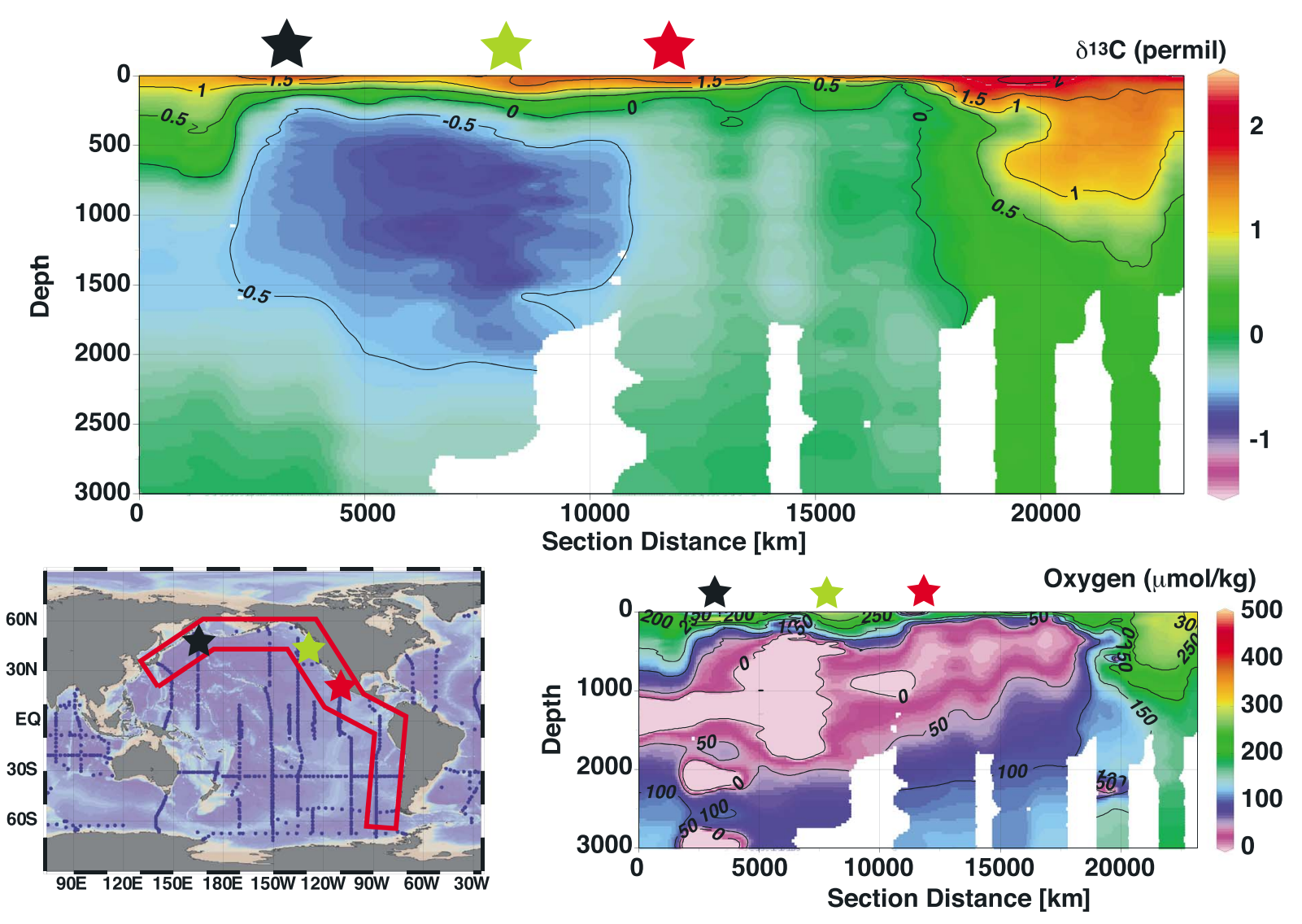

Figure 1. NW-SE Pacific transection of $\delta^{13} \mathrm{C}$ and oxygen concentration in the Pacific at intermediate depth. The colored stars indicate the location of the key sites on the map along the transects. Data are from Schmittner et al. [2013].

inorganic carbon $\delta^{13} \mathrm{C}\left(\delta^{13} \mathrm{C}_{\mathrm{DIC}}\right)$ [Kroopnick, 1985], one parameter that tracks changes in oxygen and nutrient concentrations in the ocean [Kroopnick, 1985] (Figure 1).

In this study we focus on the glacial distribution of $\delta^{13} \mathrm{C}_{\mathrm{DIC}}$ at intermediate depth in the Pacific by reconstructing its distribution along four stations in the Pacific. The $\delta^{13} \mathrm{C}_{\mathrm{DIC}}$ in the ocean is mainly controlled by the balance between the preferential biological uptake of ${ }^{12} \mathrm{C}$ relative to ${ }^{13} \mathrm{C}$, ocean-atmosphere $\mathrm{CO}_{2}$ exchange at sea surface, and the decomposition of organic matter in the water column, as well as by large-scale oceanic circulation at depth [Broecker and Peng, 1982; Schmittner et al., 2013]. Since certain epibenthic foraminifera such as Cibicidoides and Cibicides species calcify their tests close to the $\delta^{13} \mathrm{C}$ of the bottom water where they live [Woodruff et al., 1980; Belanger et al., 1981; Graham et al., 1981; Zahn et al., 1986], their carbon isotopic composition has been successfully used to reconstruct past ocean circulation [e.g., Duplessy et al., 1984; Keigwin, 1987; Curry et al., 1988; Duplessy et al., 1988; Oppo et al., 1990; van Geen et al., 1996; Keigwin, 1998; Stott et al., 1999; Lund and Mix, 1998; Matsumoto and Lynch-Stiegliz, 1999; Matsumoto et al., 2001, 2002; Curry and Oppo, 2005; Hill et al., 2006; Herguera et al., 2010].

Regional hydrographic reconstructions based on epibenthic foraminifera in the northwest Pacific (NWP) provided evidence for the existence of a distinct hydrographic boundary at $2000 \mathrm{~m}$ depth during the Last Glacial Maximum (LGM) that separated an upper layer of nutrient-poor (higher $\delta^{13} \mathrm{C}$ ) waters from deeper nutrient-rich (lower $\delta^{13} \mathrm{C}$ ) waters [Keigwin, 1998; Herguera et al., 1992; Matsumoto and Lynch-Stiegliz, 1999; Matsumoto et al., 2001, 2002; Herguera et al., 2010]. Because certain environmental conditions such as high organic matter flux to the seafloor and/or low oxygen concentration preclude the existence of epibenthic species [e.g., Jorissen et al., 1995], several authors have opted to use endobenthic species (e.g., species of Uvigerina, Bolivina, and Epistominella among others) to characterize past oceanic circulation after applying a habitat-dependent isotopic correction factor to the carbon and oxygen isotopic measurements [Shackleton, 1974; Duplessy et al., 1984; Mix et al., 1991; Lund and Mix, 1998; Kwiek and Ravelo, 1999; 
Anderson et al., 2001; Hall et al., 2001; Katz et al., 2003; Ohkushi et al., 2003]. Generally, pore water $\delta^{13} C_{\mathrm{DIC}}$ values rapidly decrease with increasing depth in the sediment within the top centimeter [McCorkle et al., 1985]. Calcitic tests of infaunal species are therefore expected to generally display lower $\delta^{13} \mathrm{C}$ values as compared to epibenthic species [McCorkle et al., 1990] and may alter the integrity of endobenthic foraminifera $\delta^{13} \mathrm{C}$ values to reconstruct that of oceanic $\delta^{13} \mathrm{C}_{\mathrm{DIC}}$.

Using exclusively epibenthic species will however eventually lead to the undersampling of those oceanic regions where dysoxic conditions are unfavorable to the subsistence of epibenthic species. Yet these oceanic zones are critical to the understanding of the Pacific OMZ variability, so that further approaches and application efforts to combine multiple species having contrasting tolerance with respect to bottom water oxygen content are warranted. In this study we calibrate and carefully use epibenthic and shallow endobenthic foraminifera stable isotopes to estimate glacial values of $\delta^{13} \mathrm{C}_{\mathrm{DIC}}$, to visualize the distribution of glacial Pacific Ocean $\delta^{13} C_{\text {DIC }}$. We present new stable isotope records at four sites spanning the 400- 1300 m water depth range along the western margin of southern Baja California, from an area hereafter referred to as the Magdalena Margin [Ortiz et al., 2004]. The intensity of the OMZ in that area is particularly pronounced, inhibiting bioturbation over the past $\sim 10 \mathrm{kyr}$ in the depth range of 500-1200 m [van Geen et al., 2003]. The new stable isotopic records from the OMZ-depth range where U. peregrina and C. mackannai were present allow us to constrain the oceanographic changes that occurred between the LGM and the Holocene and to compare it with distant Pacific sites to envision the oxygen and/or nutrient redistribution that occurred during the last deglaciation in the Pacific Ocean at intermediate depth.

\section{Hydrographic Setting}

The cores studied here consist of a set of gravity, piston, and multicores that were collected along the western margin of Baja California in 1999 [van Geen and Scientific Party R/V Melville, 2001; van Geen et al., 2003], as well as surface sediments collected in 2006 with a Smith-McIntyre grab sampler. The four coring sites of this study are located on the open margin (Figure 2) and are presently under the influence of two water masses. The North Pacific Intermediate Water (NPIW) is formed today in the Oyashio Front [Talley, 1993], in the Sea of Okhotsk [Talley, 1991], and the Alaska Gyre [Van Scoy et al., 1991]. At formation site, the NPIW is characterized by a salinity minimum, elevated oxygen concentration, and a density range of $\sigma_{\Theta}=26.7-26.9$ [Reid, 1965]. This density surface is centered on a depth of about $400 \mathrm{~m}$ on the Magdalena Margin [van Geen et al., 2006]. Here the signature of NPIW is eroded from below by mixing with a more saline, oxygen-depleted water mass of subtropical origin [Schmitz, 1995], the Equatorial Subsurface Water (ESSW), that has been observed to occur even at $1500 \mathrm{~m}$ depth in the ENP [Tsuchiya, 1981]. This water mass flows eastward along the equator across the Pacific to later veer poleward as an undercurrent in both hemispheres. Although the initial oxygen content of ESSW is high, much of it is consumed by the time it reaches the Mexican and Peruvian Margins, mainly by remineralization of organic matter generated in the productive overlying waters [Wyrtki, 1967]. Below $1200 \mathrm{~m}$ depth, the deep Pacific Ocean consists of a water mass of southern origin, the Antarctic Bottom Water, whose density declines along its northward path as a result of heat diffusion from above, and geothermal heating from below, that later flows backward as Pacific Deep Water (PDW) before upwelling at the Antarctic divergence [Emile-Geay et al., 2007]. Around the southern end of Baja California, PDW is characterized by lower nutrient concentrations than those found at intermediate waters [Bustos-Serrano and Castro-Valdez, 2006].

\section{Methods}

\subsection{Site Description}

Whereas modern salinity is relatively constant $(34.52 \pm 0.02)$ within the $400-1300$ depth range of the core sampling sites, the temperature and oxygen content of the water column vary significantly with water depth (Table 1). The water column is suboxic at the two sites where cores MV99-GC31/PC08 and MV99-GC32/PC10 were collected ( 1 and $2 \mu \mathrm{mol} / \mathrm{kg}$ dissolved oxygen, respectively), whereas oxygen concentration is significantly higher at the two deeper sites (11 and $32 \mu \mathrm{mol} / \mathrm{kg}$ and MV99-GC37 and MV99-GC38, respectively).

Laminations are clearly visible in the upper $\sim 3 \mathrm{~m}$ of cores GC32 and GC31 (the MV99 cruise label will be hereon omitted), whereas the sediments in cores GC37 and GC38 are generally homogeneous with some occasional burrows [van Geen et al., 2003]. Radiocarbon dating indicates that the upper laminated sediments 

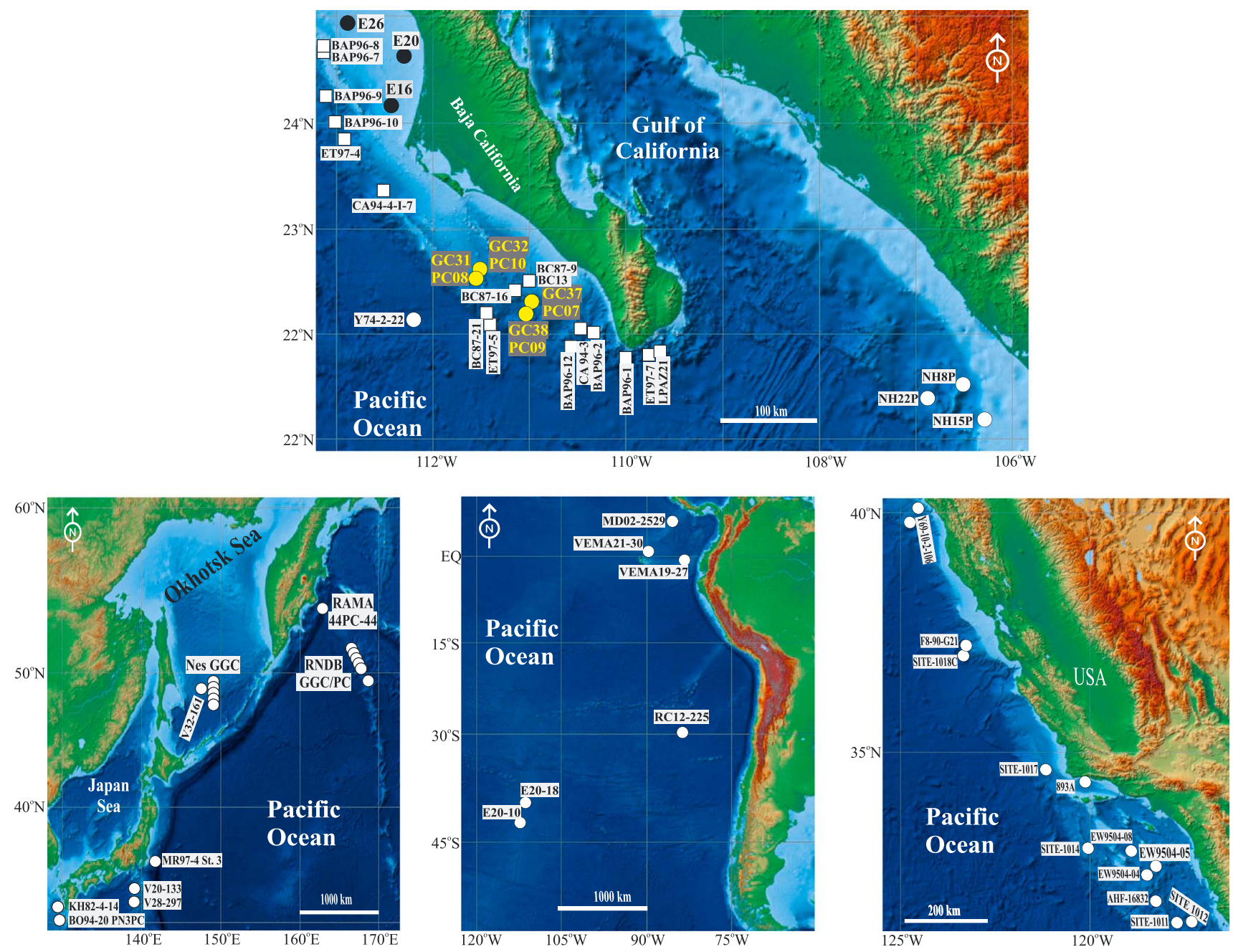

Figure 2. Study area with coring sites (white circles) used to reconstruct the hydrography and circulation of the (a) northeastern Pacific. Other sites used in this paper are also depicted as white squares: (b) northwest Pacific, (c) southeast Pacific, and (d) northeast Pacific, respectively. Surface sediments are marked with black circles and ID, and core sediments are marked with yellow circles and ID.

in GC32 and GC31 are Holocene in age; sediments in these localities were deposited at an average rate of 22 and $30 \mathrm{~cm} / \mathrm{kyr}$, respectively [van Geen et al., 2003]. Radiocarbon dates of the gravity core/piston pairs GC31-PC08, GC32-PC10, and GC38-PC09 were published in van Geen et al. [2003] and Marchitto et al. [2007]. By ${ }^{14} \mathrm{C}$ dating of the core tops of GC31, GC32, and GC38, the absolute ages obtained were $0.7 \mathrm{ka}$, $1.4 \mathrm{ka}$, and $8.3 \mathrm{ka}$, respectively. The age model of core GC37 was developed by isotopic stratigraphy by aligning the $\delta^{18} \mathrm{O}$ changes recorded in benthic foraminifera from this core with that from the other three cores where radiocarbon dates are available. Five tie points were used to develop the age model. This

Table 1. Locations, Hydrographic Data, and Sediment Type in Holocene for Magdalena Margin, Baja California Sur, Mexico

\begin{tabular}{lccccccc} 
Core Site & Latitude $\left({ }^{\circ} \mathrm{N}\right)$ & Longitude $\left({ }^{\circ} \mathrm{W}\right)$ & Depth $(\mathrm{m})$ & $T\left({ }^{\circ} \mathrm{C}\right)$ & Salinity & Oxygen $\mu \mathrm{mol} / \mathrm{kg}$ & Sediment Type \\
\hline GC32, PC10 & 23.61 & 111.56 & 433 & 8.7 & 34.5 & 1.3 & Laminations \\
GC31, PC08 & 23.47 & 111.6 & 686 & 6 & 34.5 & 2.3 & Laminations \\
GC37 & 23.33 & 111.02 & 978 & 4.6 & 34.4 & 11.4 & Burrows \\
GC38 & 23.22 & 111.08 & 1269 & 3.5 & 34.6 & 32 & Homogeneous \\
\hline
\end{tabular}


enabled to define the Holocene/Last Glacial Period boundary (LGP, $10.7 \mathrm{ka}$ ) at $90 \mathrm{~cm}$, the LGP/marine isotope stage (MIS) 3 transition $(24.9 \mathrm{ka}$ ) at $292 \mathrm{~cm}$, the MIS $3 / 4$ transition $(57.3 \mathrm{ka}$ ) at $6720 \mathrm{~cm}$, and the MIS $4 / 5$ transition $(70.9 \mathrm{ka})$ at $834 \mathrm{~cm}$. The Last Glacial Maximum (LGM) occurring at 19.2-18.8 ka was identified at $190-195 \mathrm{~cm}$ and exhibits the latest heaviest oxygen isotope event (4.13-4.16\%o). We dated the core top assuming that the upper portion of the core was affected by a sedimentation rate similar than that calculated during the deglaciation. The extrapolation provides an age of $5.6 \mathrm{ka}$ for the top of GC37.

The surface sediments collected in the depth range of 70-400 $\mathrm{m}$ (see Table 1) have not been dated. Previous analysis confirmed that the grab samples were undisturbed, and only the top $2 \mathrm{~cm}$ were collected from the center of the grab sampler. Assuming that sedimentation rate is $22 \mathrm{~cm} / \mathrm{kyr}$ (as seen in cores GC32/PC10, collected at $430 \mathrm{~m}$ depth), the extrapolated age for the top $2 \mathrm{~cm}$ of the grab samples represents an integrated period of the last 50 to 100 years.

\subsection{Stable Isotope Measurements}

Sediment samples were washed and wet sieved at 250, 125, and $63 \mu \mathrm{m}$. Foraminifera were picked manually under a stereoscopic microscope, oven dried, and stored in vials. Before analyses, foraminifera samples were heated at $350^{\circ} \mathrm{C}$ in order to eliminate potential organic traces. Between 5 and 11 foraminifera tests within the 125-250 $\mu \mathrm{m}$ size fraction were used for each isotopic analysis.

The $\delta^{18} \mathrm{O}$ and $\delta^{13} \mathrm{C}$ of Uvigerina peregrina and Cibicides mckannai (reported in \%o versus Pee Dee belemnite (PDB)) were measured using an isotope ratio mass spectrometer (OPTIMA) interfaced with an automated common acid bath (ISOCARB) at the Instituto de Investigaciones Oceanológicas of the Universidad Autónoma de Baja California, Ensenada, Mexico. The external precision of the isotopic measurements was $<0.04 \%$ o for both $\delta^{18} \mathrm{O}$ and $\delta^{13} \mathrm{C}$. The isotopic measurements were calibrated against NBS-19 (National Bureau of Standards) and an in-house working standard (M-IIO). The $\delta^{18} \mathrm{O}$ and $\delta^{13} \mathrm{C}$ of U. peregrina, C. mckannai, and $C$. wuellerstorfi of the surface sediments were measured using a Finnigan Deltaplus $V$ isotope ratio mass spectrometer coupled to a Gas Bench II, at the Centro Interdisciplinario de Ciencias Marinas's Stable Isotope Laboratory of the Instituto Politecnico Nacional (IPN) of Mexico. The precisions of the measurements were better than $0.05 \%$ ofor $\delta^{18} \mathrm{O}$ and $\delta^{13} \mathrm{C}$ and were calibrated against a NBS-19 standard.

\subsection{Selection of Additional Sites}

We built a database of stable isotopic records for 18 sites selected from the NWP (off Japan and Russia), 44 sites from the northeast Pacific (NEP) (off California, Baja California, and Mazatlan), and 6 sites from the southeast Pacific (SEP) (off Chile) (Figure 2). The selection of those sites was based on the presence of U. peregrina, C. wuellerstorfi, or C. mckannai and on the existence of radiocarbon dates and oxygen isotope analysis to ensure the sampling of the Holocene (11 to $0 \mathrm{ka}$ ) and Last Glacial Maximum ( 22 to $18 \mathrm{ka}$ ) periods. The resulting compilation has previously been reported to adequately capture the large-scale variation of the modern hydrography in the NEP as seen in the spatial distribution of $\delta^{13} C_{\mathrm{DIC}}$ [e.g., Kroopnick, 1985; Kwiek and Ravelo, 1999; Stott et al., 1999]. Thirteen of the selected sites are located north of $30^{\circ} \mathrm{N}$ and range between 950 and $2100 \mathrm{~m}$ in depth (with the exception of core $893 \mathrm{~A}$ from Santa Barbara Basin). The 28 remaining sites south of $30^{\circ} \mathrm{N}$ span the $70-2100 \mathrm{~m}$ depth range. There are only three isotopic records consisting of carbon and oxygen isotope records collected from depths shallower than $1300 \mathrm{~m}$ reliable for studying past water mass changes, namely, the Ocean Drilling Program (ODP) site 893, ODP site 1017, and ODP site 1014. Of these, only ODP site 1014 and ODP site 893A consist in published carbon and oxygen isotopes for the key period of interest (i.e., Holocene to LGM), while published isotopic results at ODP site 1017 consist in oxygen isotopes but not of carbon (Table 2).

\section{Results}

\subsection{Interspecies Calibration on the Magdalena Margin}

The two species $C$. wuellerstorfi and C. mckannai that are widely believed to form their shells close to oxygen and carbon isotopic equilibrium with the surrounding environment [Kim and O'Niel, 1997; Stott et al., 1999] are essentially restricted to bioturbated intervals in the Magdalena Margin cores. $U$. peregrina was present throughout the entire length of the cores studied. Cores GC31 and GC32 (Figures 3a, 3b, 3e, and 3f) contain almost complete Holocene sequences, while cores GC37 and GC38 record only the early part of Holocene (Figures 3c, 3d, 3g, and 3h). The LGM is recorded in cores PC08, GC37, and GC38 either by U. peregrina and C. mckannai. 
Table 2. Oxygen and Carbon Stable Isotopes in the Cores of the Magdalena Margin, Southwestern Baja California, Mexico

\begin{tabular}{|c|c|c|c|c|}
\hline Core ID & Depth (m) & Age (ka) & $\delta^{13} \mathrm{C}$ & $\delta^{18} \mathrm{C}$ \\
\hline GC32-2-0 & 0.26 & -0.142 & -0.903 & 1.860 \\
\hline GC32-2-20 & 0.45 & 0.868 & -0.771 & 1.843 \\
\hline GC32-2-40 & 0.65 & 1.909 & -0.409 & 1.943 \\
\hline GC32-2-60 & 0.85 & 2.929 & -0.688 & 1.913 \\
\hline GC32-2-70 & 0.95 & 3.431 & -0.834 & 1.980 \\
\hline GC32-2-100 & 1.25 & 4.905 & -0.672 & 2.032 \\
\hline GC32-2-120 & 1.45 & 5.861 & -0.643 & 2.035 \\
\hline GC32-2-140 & 1.65 & 6.796 & -0.622 & 1.984 \\
\hline GC32-1-0 & 1.76 & 7.301 & -0.779 & 2.160 \\
\hline GC32-1-20 & 1.95 & 8.158 & -0.805 & 2.284 \\
\hline GC32-1-65 & 2.35 & 9.899 & -1.042 & 2.378 \\
\hline GC32-1-100 & 2.7 & 11.353 & -1.076 & 2.717 \\
\hline PC10-10-20 & 1.84 & 8.985 & -1.074 & 3.061 \\
\hline PC10-10-60 & 2.24 & 10.936 & -1.318 & 3.141 \\
\hline PC10-9-20 & 2.77 & 13.521 & -1.325 & 3.587 \\
\hline PC10-9-50 & 3.07 & 14.985 & -1.354 & 3.641 \\
\hline GC31-3-10 & 0.350 & 0.779 & -0.095 & 2.200 \\
\hline GC31-3-30 & 0.550 & 1.464 & -0.335 & 2.110 \\
\hline GC31-3-70 & 0.950 & 2.836 & -0.135 & 2.100 \\
\hline GC31-3-90 & 1.150 & 3.522 & -0.285 & 2.040 \\
\hline GC31-3-110 & 1.350 & 4.207 & -0.345 & 2.070 \\
\hline GC31-3-130 & 1.550 & 4.893 & -0.145 & 2.070 \\
\hline GC31-3-150 & 1.750 & 5.579 & -0.125 & 2.070 \\
\hline GC31-2-20 & 1.950 & 6.264 & -0.185 & 2.120 \\
\hline GC31-2-40 & 2.150 & 6.950 & -0.875 & 2.210 \\
\hline GC31-2-60 & 2.350 & 7.636 & -0.635 & 2.200 \\
\hline GC31-2-80 & 2.550 & 8.321 & -0.725 & 2.390 \\
\hline GC31-2-140 & 3.150 & 10.378 & -1.075 & 2.450 \\
\hline GC31-1-20 & 3.370 & 11.133 & -1.295 & 2.480 \\
\hline GC31-1-40 & 3.570 & 11.818 & -1.355 & 2.910 \\
\hline GC31-2-60 & 2.350 & 7.636 & -0.635 & 2.200 \\
\hline GC31-2-80 & 2.550 & 8.321 & -0.725 & 2.390 \\
\hline GC31-2-140 & 3.150 & 10.378 & -1.075 & 2.450 \\
\hline GC31-1-20 & 3.370 & 11.133 & -1.295 & 2.480 \\
\hline GC31-1-40 & 3.570 & 11.818 & -1.355 & 2.910 \\
\hline GC31-2-60 & 2.350 & 7.636 & -0.635 & 2.200 \\
\hline GC31-2-80 & 2.550 & 8.321 & -0.725 & 2.390 \\
\hline GC31-2-140 & 3.150 & 10.378 & -1.075 & 2.450 \\
\hline GC31-1-20 & 3.370 & 11.133 & -1.295 & 2.480 \\
\hline GC31-1-40 & 3.570 & 11.818 & -1.355 & 2.910 \\
\hline GC31-2-60 & 2.350 & 7.636 & -0.635 & 2.200 \\
\hline GC31-2-80 & 2.550 & 8.321 & -0.725 & 2.390 \\
\hline PC8-8-80 & 5.12 & 17.132 & -0.849 & 3.591 \\
\hline PC8-8-100 & 5.32 & 17.818 & -0.658 & 3.574 \\
\hline PC8-8-120 & 5.52 & 18.504 & -1.051 & 3.736 \\
\hline PC8-7-10 & 5.91 & 19.841 & -1.309 & 3.826 \\
\hline PC8-7-30 & 6.11 & 20.526 & -0.942 & 3.552 \\
\hline PC8-7-50 & 6.31 & 21.212 & -0.794 & 3.751 \\
\hline PC8-7-80 & 6.61 & 22.241 & -0.975 & 3.785 \\
\hline PC8-7-100 & 6.81 & 22.926 & -0.940 & 3.512 \\
\hline PC8-7-120 & 7.01 & 23.612 & -0.876 & 3.588 \\
\hline PC8-7-140 & 7.21 & 24.298 & -0.915 & 3.746 \\
\hline GC37-2-0 & 0.260 & 5.608 & -0.534 & 2.651 \\
\hline GC37-2-15 & 0.400 & 6.738 & -0.474 & 2.549 \\
\hline GC37-2-20 & 0.450 & 7.142 & -0.478 & 2.521 \\
\hline GC37-2-30 & 0.550 & 7.949 & -0.565 & 3.005 \\
\hline GC37-2-55 & 0.800 & 9.966 & -0.577 & 3.109 \\
\hline GC37-2-75 & 1.000 & 11.580 & -0.808 & 2.946 \\
\hline GC37-2-95 & 1.200 & 13.194 & -0.806 & 3.876 \\
\hline GC37-2-130 & 1.550 & 16.019 & -1.144 & 3.986 \\
\hline GC37-2-145 & 1.700 & 17.229 & -0.729 & 4.131 \\
\hline
\end{tabular}


Table 2. (continued)

\begin{tabular}{lcccc} 
Core ID & Depth $(\mathrm{m})$ & Age $(\mathrm{ka})$ & $\delta^{13} \mathrm{C}$ & $\delta^{18} \mathrm{C}$ \\
\hline GC37-1-5 & 1.800 & 17.633 & -0.636 & 4.114 \\
GC37-1-20 & 1.950 & 19.247 & -0.707 & 4.161 \\
GC37-1-30 & 2.050 & 20.054 & -1.167 & 4.079 \\
GC37-1-50 & 21.668 & -0.855 & 4.066 \\
GC37-1-70 & 2.250 & 23.282 & -0.762 & 3.983 \\
GC38-2-0 & 2.450 & 8.379 & -0.742 & 3.278 \\
GC38-2-20 & 0.250 & 9.885 & -0.791 & 3.419 \\
GC38-2-40 & 0.450 & 11.390 & -0.726 & 3.651 \\
GC38-2-60 & 0.650 & 12.896 & -0.886 & 4.353 \\
GC38-2-80 & 14.402 & -1.072 & 3.993 \\
GC38-2-100 & 1.850 & 15.907 & -1.056 & 3.892 \\
GC38-2-120 & 1.050 & 17.413 & -0.964 & 3.852 \\
GC38-2-140 & 1.250 & 18.918 & -0.815 & 3.750 \\
GC38-1-0 & 1.450 & 19.747 & -1.139 & 3.988 \\
GC38-1-20 & 1.650 & 21.252 & -1.033 & 3.805 \\
GC38-1-40 & 1.760 & 22.758 & -1.141 & 3.718 \\
GC38-1-60 & 1.960 & 24.263 & -1.122 & 3.816 \\
\hline
\end{tabular}

Contrasting oxygen and carbon isotopic values are commonly found between cooccurring Uvigerina and Cibicides species and are thought to be linked to a combination of vital and microhabitat effects. A constant offset of $0.64 \%$ reported in Shackleton and Opdyke [1973] is a robust feature of interspecific $\delta^{18} \mathrm{O}$ difference between both species. Although this value has recently been suggested by Marchitto et al. [2014] to be lower $(0.47 \%)$ in core top measurements from the Florida Straits and the Arctic Ocean, high-resolution $\delta^{18} \mathrm{O}$ records derived from both species from the same sequence have proven the historical value of $0.64 \%$ o to be remarkably reproducible in the eastern tropical Pacific at intermediate depth [see, e.g., Leduc et al., 2007].

The $\delta^{13} \mathrm{C}$ offset is not constant between the species, however, and several parameters have been suggested to alter the interspecific $\delta^{13} \mathrm{C}$ offset. In very high primary productivity environments such as the Southern Ocean, intense fluxes of particulate organic carbon to the sediment can lead to the development of an organic-rich phytodetritus "fluffy layer" situated just above the sediment-water interface, where epibenthic foraminifera live [Mackensen et al., 1993]. This layer hosts intense decomposition of organic matter that artificially lowers the $\delta^{13} \mathrm{C}_{\mathrm{DIC}}$ of the bottom seawater, leading the epibenthic foraminifera to capture a $\delta^{13} \mathrm{C}$ from ambient water anomalously low because of that artifact-the so-called "Mackensen effect" [Mackensen et al., 1993]. This Mackensen effect has the potential to lower the difference between the $\delta^{13} \mathrm{C}$ values of $C$. wuellerstorfi and that of $U$. peregrina (hereafter referred to as $\Delta \delta^{13} C_{\text {wuell-pereg) }}$ ) by up to $0.3 \%$ o below the $0.9 \%$ value initially suggested by Duplessy et al. [1984]. The Mackensen effect is however generally thought to occur mainly in the South Atlantic and circum-Antarctic Oceans [Mackensen et al., 2001; Bickert and Mackensen, 2004].

In other regions where high primary productivity prevails, intense decomposition of organic matter within the sediment can lead to the formation of anomalously ${ }^{13} \mathrm{C}$-depleted pore water, subsequently lowering the $\delta^{13} \mathrm{C}$ signature of endobenthic foraminifera relative to the epibenthic foraminifera [Zahn et al., 1986].

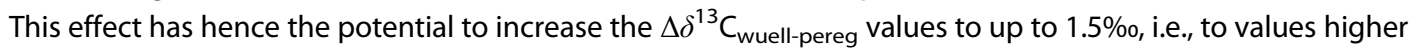
by $\sim 0.6 \%$ o higher than those suggested by Duplessy et al. [1984].

More generally, the burial of partially degraded organic matter into the sedimentary column appears to be the main parameter controlling the composition and the vertical distribution of benthic foraminiferal faunas below the sediment-water interface [Fontanier et al., 2002]. This effect should also be reflected as an increase in the $\delta^{13} \mathrm{C}$ gradient between the epibenthic and endobenthic foraminifera if the so-called "microhabitat effect" was at play at our study site [Fontanier et al., 2006].

Those above-mentioned parameters point to the general difficulty to interpret $\delta^{13} \mathrm{C}$ of $U$. peregrina that can at least partly be attributed to the $U$. peregrina ecology. Pore water $\delta^{13} \mathrm{C}_{\mathrm{DIC}}$ measurements indicate that the steepest pore water $\delta^{13} C_{\text {DIC }}$ gradient is always found in the upper $2 \mathrm{~cm}$ of sediment [McCorkle et al., 1985], i.e., within the habitat depth interval of U. peregrina [McCorkle et al., 1997]. Thus, the $\delta^{13} \mathrm{C}$ of U. peregrina may be highly sensitive to minor shifts in the vertical $\delta^{13} C_{D I C}$ gradient of pore waters that may evolve in 

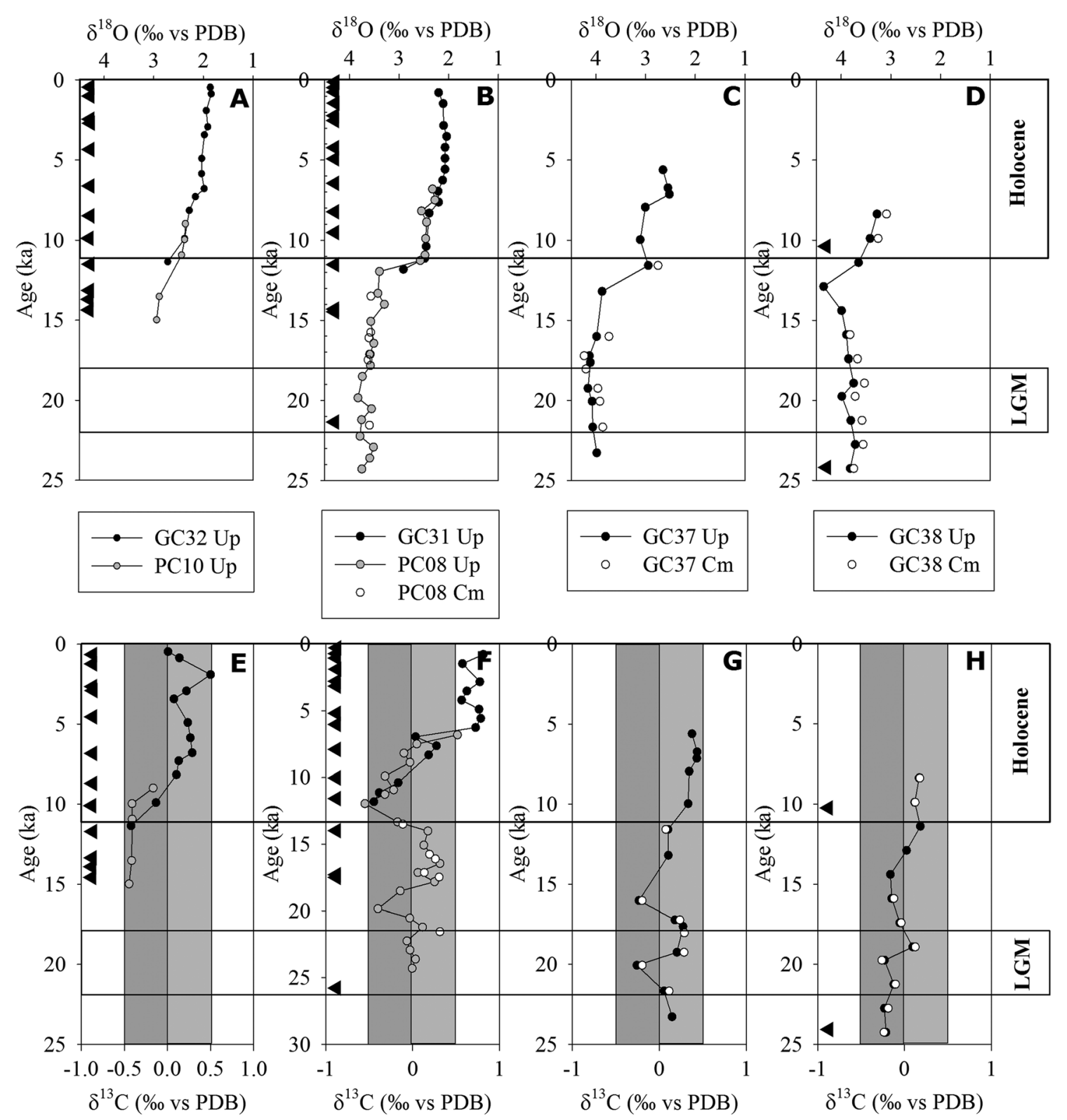

Figure 3. The $\delta^{18} \mathrm{O}$ and $\delta^{13} \mathrm{C}$ profiles of Uvigerina peregrina (corrected, see text, gray and black circles) and Cibicides mckannai (white circles) from the Magdalena margin. (a and e) Core GC32 and PC10 from $430 \mathrm{~m}$ depth. (b and f) Core GC31 and PC08 from $705 \mathrm{~m}$ depth. (c and g) Core GC38 from $1200 \mathrm{~m}$ depth. (d and h) Core GC37 from $970 \mathrm{~m}$ depth. The black triangles in cores GC32 and PC10, GC31 and PC08, and GC38 denote the depth in cores where ${ }^{14} \mathrm{C}$ dating was performed [from van Geen et al., 2003]. The age model of core GC37 was obtained by comparing the $\delta^{18} \mathrm{O}$ signal with the other cores from the Magdalena Margin.

parallel with changes in organic matter fluxes to the seafloor. In sedimentary environments where oxygen and food is not limiting, however, $U$. peregrina can migrate to adapt to the sedimentary environment that fits best to its optimal environmental conditions in terms of food [Loubere et al., 1995] and oxygen levels [Geslin et al., 2004]. As an example, a 10 month temporal survey revealed that the $\delta^{13} \mathrm{C}$ of $U$. peregrina variations were related to core and subcore variability rather than to seasonal changes in phytodetritus fluxes to the seafloor [Corliss et al., 2002]. It then appears that when food is always abundant enough such as along the Magdalena Margin and when strictly anoxic conditions are not reached, then using the $\delta^{13} \mathrm{C}$ of $U$. peregrina as a proxy for $\delta^{13} \mathrm{C}_{\mathrm{DIC}}$ can lead to valid results.

Comparison of oxygen and carbon isotope data for Uvigerina and Cibicides species in our cores and in surface sediments, when both species cooccur, indicates a remarkably constant offset of $-0.6 \pm 0.2 \%$ o for 

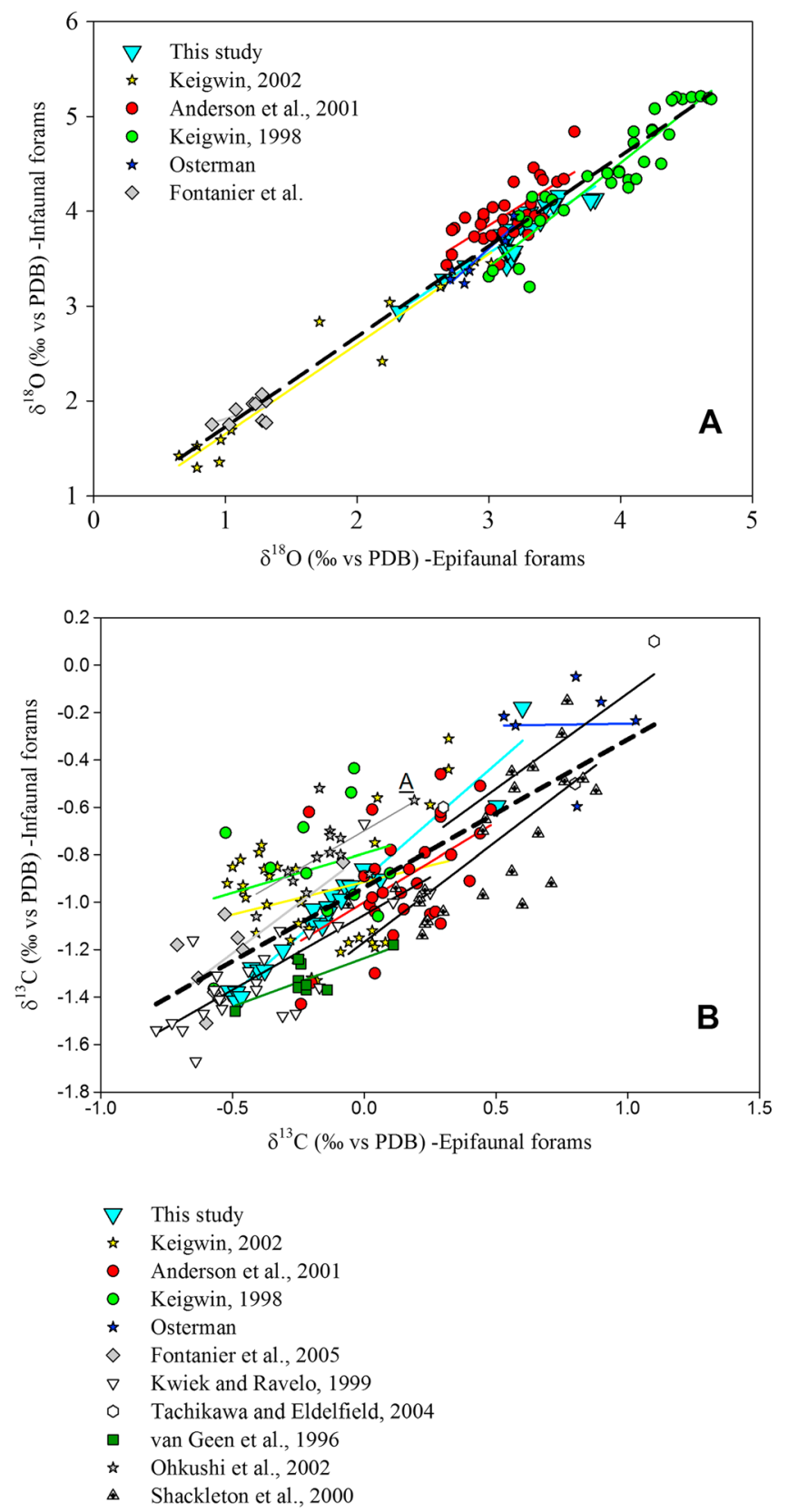

Figure 4. Stable isotopic relationship of (a) oxygen and (b) carbon between cooccurring endobenthic foraminifera (U. curticosta and U. peregrina) and epibenthic foraminifera (Cibicidoides spp., C. wuellerstorfi, C. mckannai, Planulina arimensis, and $P$. wuellerstorf). The slopes ( $m$, color lines) correspond to ${ }^{13} \mathrm{C}$ values of both types of foram species measured simultaneously at the same core levels. The slope values for $\delta^{18} \mathrm{O}$ for the same species are not shown because they are very similar for the sites where both species were measured. The black dashed lines represent the regression line of all the isotopic values of oxygen and carbon where both foraminifera types were simultaneously measured at the same core levels, including the intercept (m) and $r$ values $\left(\delta^{18} \mathrm{O}, m=0.77\right.$, and $r=0.96 ; \delta^{13} \mathrm{C}, m=-0.93$, and $\left.r=0.74\right)$.
$\Delta \delta^{18} \mathrm{O}_{\text {wuell-pereg }}$ and $+0.9 \pm 0.1 \%$ o for

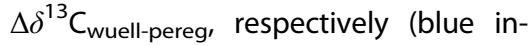
verted triangle, Figure 4). These values are perfectly in line with the offsets reported in the literature for those two species that were initially reported from oceans oxygenated more than the NEP [Shackleton and Opdyke, 1973; Duplessy et al., 1984]. It suggests that those values can be used to infer past changes in the water column $\delta^{13} C_{\text {DIC }}$ along the Magdalena Margin through applying those species-specific isotopic offsets to account for vital and/or microhabitat effects. For instance, the correlation between these species is statistically significant for oxygen $\left(r=0.96 ; F_{1,129}\right.$, $\alpha=0.05=1114.0 ; P<0.0001$; Figure 4a) and for carbon $\left(r=0.73 ; \quad F_{1,149}\right.$, $\alpha=0.05=114.5 ; P<0.001$; Figure $4 b$ ), with a $\delta^{13} \mathrm{C}$ offset ranging from -0.70 to $-1.2 \%$ o for all the oceans.

As compared to the interspecies offset seen in the $\Delta \delta^{18} \mathrm{O}_{\text {wuell-peregr }}$ which aligns along a 1:1 line with near perfection, the spread of the $\Delta \delta^{13} \mathrm{C}_{\text {wuell-pereg }}$ of benthic foraminifera is clearly affected by processes that vary from site to site. The compilation done in Figure 4 encompasses a multitude of oceanic environments that can explain the spread of the $\Delta \delta^{13} C_{\text {wuell-pereg, original }}$ publications from which the $\Delta \delta^{13} C_{\text {wuell- }}$ pereg assembled in Figure $4 \mathrm{~b}$ report a large array of processes likely affecting the interspecies $\delta^{13} \mathrm{C}$ offset. In some places, multiple factors may be responsible for the $\delta^{13} \mathrm{C}$ offset, which make it difficult to attribute the respective contribution of those entangled parameters. For example, in the Gulf of California and Namibia upwelling system, both changes in lateral water mass advection and in exported productivity can occur [Anderson et al., 2001; Keigwin, 2002]. Also, in Tanner Basin, both exported productivity and the mixing of different morphotypes may be responsible for the spreading of the $\delta^{13} \mathrm{C}$ offset [Kwiek and Ravelo, 1999].

Bioturbation has also been suggested to alter the $\delta^{13} \mathrm{C}$ offset in Shatsky Rise, where very low sedimentation rates occur [Ohkushi et al., 2003]. All of those factors listed above may be at work, though, so it is virtually impossible to precisely disentangle how much one mechanism in particular contributes to obscure the 
original water isotopic signature. More generally, however, exported productivity and its associated organic matter decay within the sediment is probably the first-order parameter affecting the spreading of the interspecies $\delta^{13} \mathrm{C}$ offset. It has been reported to be the case in the northwest Pacific [Keigwin, 1998], the North Atlantic [Osterman et al., 2000], the Gulf of California [Keigwin, 2002], the Bay of Biscay [Fontanier et al., 2006], the northeastern Atlantic [Tachikawa and Elderfield, 2002], and off central California [van Geen et al., 1996]. We hence hypothesize that differences in regional primary productivity make the $\Delta \delta^{13} C_{\text {wuell-pereg }}$ being site dependent, as it is found to vary from $-0.6 \pm 0.1$ at Shatsky Rise in oligotrophic environments [Ohkushi et al., 2003] to less than -1 along the productive Iberian Margin [Shackleton et al., 2000], the Benguela upwelling system [Anderson et al., 2001], and the California upwelling system [van Geen et al., 1996].

In order to determine how biological productivity and oxygenation of the water column relate to the $\Delta \delta^{13} C_{\text {wueller-pereg }}$ in our study area, we conducted a principal component analysis to a set of exported productivity proxies previously published for the Magdalena Margin by Dean et al. [2006] and Carriquiry and Sanchez [2014b]. Factor 1, which accounts for $41 \%$ of the variability, characterizes a strong relationship

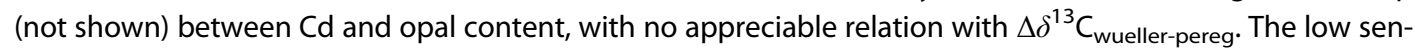

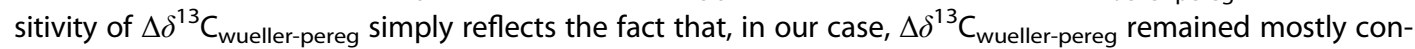

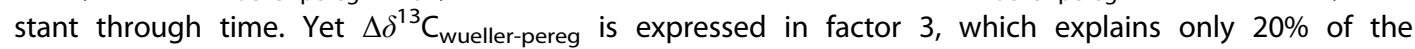
variability, and is inversely related to total organic carbon sedimentary content (TOC). If TOC were the primary driver of $\Delta \delta^{13} \mathrm{C}_{\text {wueller-pereg }}$ through its overprint on pore water $\delta^{13} \mathrm{C}$, we would expect $\Delta \delta^{13} \mathrm{C}_{\text {wueller-pereg }}$ and TOC to be positively related with each other since higher TOC may be indicative of higher potential for organic matter decay within the sediment. We hence hypothesize that differences in regional primary productivity make the $\Delta \delta^{13} \mathrm{C}_{\text {wuell-pereg }}$ being site dependent, as it is found to vary from $-0.6 \pm 0.1$ at Shatsky Rise in oligotrophic environments [Ohkushi et al., 2003] to more than -1 along the productive Iberian Margin [Shackleton et al., 2000], the Benguela upwelling system [Anderson et al., 2001], and the California upwelling system [van Geen et al., 1996].

\subsection{Bottom Water and Isotopic Composition of Foraminifera Today}

\subsubsection{Oxygen Isotopes}

The $\delta^{18} \mathrm{O}$ values of calcite in isotopic equilibrium with bottom water at different latitudes were calculated using the temperature data of Levitus and Boyer [1994] and the equation of Bemis et al. [1998]. Equation (1) is a function of temperature and isotopic composition of the seawater (in SMOW) [Epstein et al., 1953], converted to the PDB scale by subtracting $0.27 \%$ o [Hut, 1987]:

$$
T\left({ }^{\circ} \mathrm{C}\right)=16.5-4.8\left(\delta^{18} \mathrm{O}_{c}-\delta^{18} \mathrm{O}_{\mathrm{sw}}\right)
$$

Parameter $\delta^{18} \mathrm{O}_{\mathrm{sw}}$ was calculated from salinity data [Levitus et al., 1994] and from the relation of $\delta^{18} \mathrm{O}_{\mathrm{sw}}$ versus salinity (s) in the North Pacific [Keigwin, 1998].

$$
\delta^{18} \mathrm{O}_{\mathrm{sW}}=0.364-12.646
$$

Comparison of these predictions with the actual $\delta^{18} \mathrm{O}$ values measured for $U$. peregrina (corrected) and C. mckannai shows good agreement at all Magdalena Margin sites (Figure 5a, Table 3).

\subsubsection{Carbon Isotopes}

The carbon isotopic compositions of $U$. peregrina analyzed in four core tops and three surficial sediments in the depth range of 70 to $1270 \mathrm{~m}$ are consistent with the isotopic composition of Geochemical Ocean Sections Study (GEOSECS) stations from the region once the correction of $0.9 \%$ is applied (Figure $5 \mathrm{~b}$, Table 3 ), even though the two shallower cores are laminated and the two deeper cores and surficial sediments are not.

\subsection{Downcore Isotope Records}

Three out of four $U$. peregrina oxygen isotope records display the expected transition from heavy to lighter values over the course of deglaciation (Figures 3a-3d). At the $700 \mathrm{~m}$ water depth site (GC31/PC08), there is a particularly sharp $\delta^{18} \mathrm{O}$ increase of $0.91 \%$ around $11-12 \mathrm{ka}$ that coincides with the onset of laminations. At the shallower site of $400 \mathrm{~m}$ depth (GC32/PC10, Figure 3a) the shift in $\delta^{18} \mathrm{O}$ is smoother, but again straddles the onset of laminations, which occurs slightly earlier $(\sim 13 \mathrm{ka})$ at this depth. Unfortunately, the GC32/PC10 record does not extend to the LGM because of a hiatus found at sections older than $\sim 15 \mathrm{ka}$ [Dean et al., 2006]. 

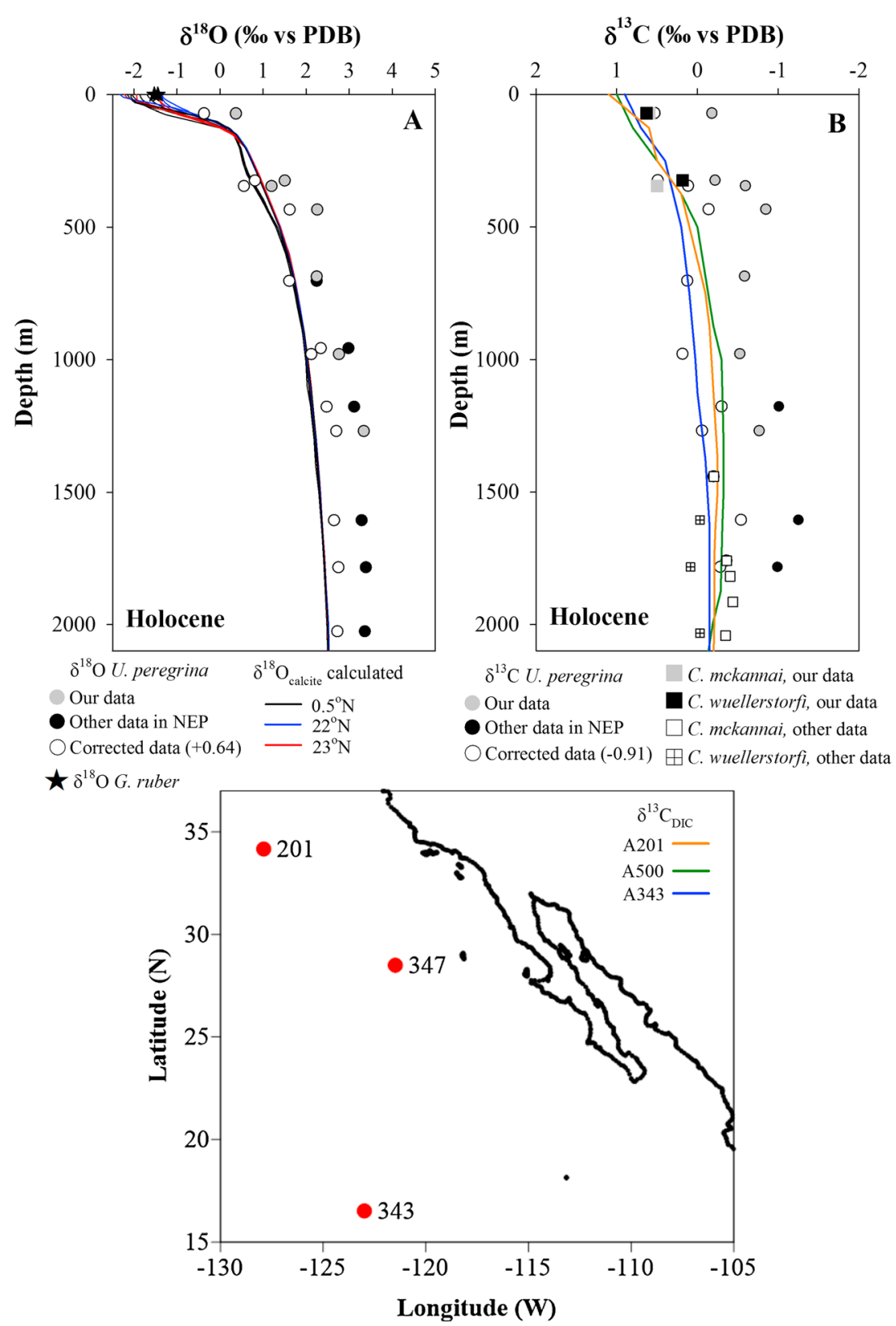

Figure 5. (a) Parameter $\delta^{18} \mathrm{O}$ of northeast Pacific benthic forams (U. peregrina (corrected), C. mckannai, and C. wuellerstorfi) as a function of depth during the Holocene. The lines represent the calculated $\delta^{18} \mathrm{O}$ of the calcite in isotopic equilibrium with seawater at different latitudes. (b) Parameter $\delta^{13} \mathrm{C}$ of northeast Pacific benthic forams (U. peregrina (corrected), C. mckannai, and C. wuellerstorfi) as a function of depth during the Holocene. The lines represent the $\delta^{13} C_{D I C}$ from which forams are supposed to precipitate their shells $\left(\delta^{13} C_{\text {DIC }}\right.$ are taken from GEOSECS stations A201, A347, and A343 situated nearby the core collection sites; see insert map) see also Table 3.

The available records indicate a LGM to Holocene shift in $\delta^{18} \mathrm{O}$ of $1.59 \%$ and $1.45 \%$ at 700 and $980 \mathrm{~m}$, respectively (Figures $3 \mathrm{~b}$ and $3 \mathrm{c}$ ). At $400 \mathrm{~m}$ depth, the shift in $\delta^{18} \mathrm{O}$ is $1.03 \%$ o between the Holocene and $15 \mathrm{ka}$ (Figure 3a). The change of $0.53 \%$ in the $\delta^{18} \mathrm{O}$ at $1270 \mathrm{~m}$ is considerably smaller (Figure 3d), implying compensating changes in the water mass temperature and/or salinity at this depth.

In general, there is a LGM to Holocene trend toward more positive $\delta^{13} \mathrm{C}$ values at the four Magdalena Margin core sites (Figures 3e-3h). Also, the records from 700 and $980 \mathrm{~m}$ depth, and perhaps $1270 \mathrm{~m}$ depth, exhibit significant fluctuations in $\delta^{13} \mathrm{C}$ over the course of the deglaciation. The average $\delta^{13} \mathrm{C}$ change for the LGM and the Holocene is 0.43 and $0.45 \%$ at 700 and $980 \mathrm{~m}$, respectively (Figures $3 \mathrm{f}-3 \mathrm{~g}$ ). At $400 \mathrm{~m}$, the increase 
Table 3. Stable Isotope Data From Different the Cores Used in This Study ${ }^{a}$

\begin{tabular}{|c|c|c|c|c|c|c|c|c|c|c|c|}
\hline \multirow[b]{2}{*}{ Core Site } & \multirow{2}{*}{$\begin{array}{l}\text { Latitude } \\
\left({ }^{\circ} \mathrm{N}\right)\end{array}$} & \multirow{2}{*}{$\begin{array}{l}\text { Longitude } \\
\text { ('W) }\end{array}$} & \multirow{2}{*}{$\begin{array}{l}\text { Depth } \\
\text { (m) }\end{array}$} & \multicolumn{2}{|c|}{ Depth Interval (m) } & \multicolumn{2}{|c|}{ Radiocarbon Age (ka) } & \multicolumn{2}{|c|}{$\delta^{18} \mathrm{O}$} & \multicolumn{2}{|c|}{$\delta^{13} \mathrm{C}$} \\
\hline & & & & Holocene & LGM & Holocene & LGM & Holocene & LGM & Holocene & LGM \\
\hline $\mathrm{E} 20^{\mathrm{b}}$ & 24.51 & 112.08 & 70.00 & $0-0.02$ & ND & SS & ND & 0.37 & ND & 0.73 & ND \\
\hline $\mathrm{E} 26^{\mathrm{b}}$ & 25.29 & -113.02 & 323.00 & $0-0.02$ & ND & SS & ND & 1.51 & ND & 0.69 & ND \\
\hline $\mathrm{E} 16^{\mathrm{b}}$ & 24.30 & 112.23 & 344.00 & $0-0.02$ & ND & SS & ND & 1.20 & ND & 0.31 & ND \\
\hline $\mathrm{NH} 15 \mathrm{P}^{\mathrm{C}}$ & 22.07 & 106.48 & 420 & $0.05-1.84$ & $23.9-25.0$ & $1.1-9.8$ & $18.0-21.6$ & 1.28 & 2.41 & ND & ND \\
\hline $\mathrm{GC} 32+\mathrm{PC} 10^{\mathrm{b}}$ & 23.61 & 111.56 & 433 & $0.26-2.4$ & - & $0.4-9.9$ & - & 2.11 & ND & -0.85 & ND \\
\hline $893-A^{d}$ & 34.29 & 120.03 & 577 & - & - & $0.05-10.0$ & $18.4-21.9$ & 1.90 & 3.37 & ND & ND \\
\hline $\mathrm{GC} 31+\mathrm{PC} 08^{\mathrm{b}}$ & 23.47 & 111.60 & 686 & $0.35-3.01$ & $5.5-6.3$ & $0.80-9.9$ & $18.5-21.2$ & 2.25 & 3.72 & -0.58 & -1.02 \\
\hline Site $1017^{\mathrm{h}}$ & 34.53 & 121.10 & 956 & $0.05-2.20$ & $3.99-4.79$ & $0.1-10.0$ & $19.1-21.9$ & 2.44 & 3.82 & ND & ND \\
\hline $\mathrm{GC} 37^{\mathrm{b}}$ & 23.33 & 111.02 & 978 & $0.26-0.80$ & $1.95-2.25$ & $5.6-9.9$ & $19.2-21.7$ & 2.77 & 4.10 & -0.53 & -1.01 \\
\hline $\mathrm{NH} 8 \mathrm{P}^{\mathrm{c}}$ & 22.39 & 107.08 & 1018 & $0.04-0.94$ & $2.14-3.19$ & $1.6-9.5$ & $18.0-21.9$ & 2.02 & 3.37 & ND & ND \\
\hline${ }^{11}$ Site 1014 & 32.83 & 119.98 & 1177 & $0.15-1.15$ & $2.25-2.65$ & $1.0-9.8$ & $18.2-21.4$ & 2.12 & 3.73 & -0.20 & -0.30 \\
\hline $\mathrm{GC} 38^{\mathrm{b}}$ & 23.22 & 111.08 & 1269 & $0.25-0.45$ & $1.65-1.96$ & $8.3-9.9$ & $18.9-21.5$ & 3.35 & 3.85 & -0.77 & -0.99 \\
\hline EW9504-08 ${ }^{f}$ & 32.80 & 118.80 & 1442 & $0.02-0.70$ & $1.37-1.59$ & $0.4-9.5$ & $18.4-21.4$ & 2.69 & 3.67 & -0.10 & -0.25 \\
\hline F8-90-G21 ${ }^{\mathrm{g}}$ & 37.22 & 123.24 & 1605 & $0.00-0.62$ & - & $0.00-9.7$ & - & 2.43 & 3.82 & ND & -0.49 \\
\hline EW9504-04 ${ }^{f}$ & 32.28 & 118.40 & 1759 & $0.02-0.72$ & $1.52-1.84$ & $1.5-9.2$ & $18.2-21.8$ & 2.33 & 3.78 & -0.31 & -0.17 \\
\hline Site $1012 \mathrm{~B}^{\mathrm{e}}$ & 32.28 & 118.38 & 1783 & $0.15-1.15$ & $2.65-2.95$ & $1.2-9.9$ & $18.1-21.8$ & 2.65 & 4.13 & -0.09 & -0.19 \\
\hline EW9504-05 ${ }^{f}$ & 32.48 & 118.13 & 1818 & $0.02-0.56$ & $1.26-1.42$ & $2.2-9.6$ & $19.2-21.4$ & 2.46 & ND & -0.26 & -0.20 \\
\hline AHF16832 & 31.67 & 118.18 & 1915 & $0.04-0.79$ & $1.87-2.30$ & $3.4-9.5$ & $18.3-21.8$ & 2.56 & 3.97 & -0.26 & -0.31 \\
\hline $\mathrm{NH} 22 \mathrm{P}^{\mathrm{C}}$ & 22.52 & 106.52 & 2025 & $0.04-0.44$ & $1.1-1.5$ & $3.4-9.7$ & $18.0-21.5$ & 2.70 & 3.99 & ND & ND \\
\hline Site $1011^{\mathrm{e}}$ & 31.28 & 117.18 & 2033 & - & - & $2.1-9.4$ & $19.7-21.7$ & 2.58 & 4.12 & -0.09 & -0.31 \\
\hline EW9504-02 ${ }^{f}$ & 31.25 & 117.58 & 2042 & $0.10-0.40$ & $0.60-0.70$ & $1.9-8.8$ & $18.4-20.6$ & 2.57 & 3.99 & -0.20 & -0.52 \\
\hline
\end{tabular}

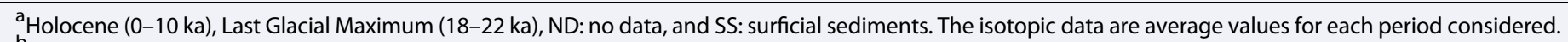

b This study.

'Ganeshram and Pedersen [1998].

dKennett and Ingram [1995].

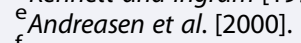

Stott et al. [2000].

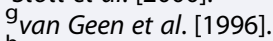

hennett et al. [2000].

in $\delta^{13} \mathrm{C}$ from $\sim 15$ ka to the Holocene is only $0.2 \%$ (Figure 3e). At $1270 \mathrm{~m}$, the shift in $\delta^{13} \mathrm{C}$ of $0.40 \%$ in the transition to Holocene conditions (Figure 3h) is not very different from the average $\delta^{13} \mathrm{C}$ for the 700 and $980 \mathrm{~m}$ water depth cores.

\section{Discussion}

\subsection{Hydrography of the Magdalena Margin During the LGM}

The sediment cores collected in the Magdalena Margin at a depth interval corresponding to the permanent thermocline allow us to study the role of water mass circulation shift that occurred at subsurficial and intermediate depths during the last deglaciation. The new isotopic records from the Magdalena Margin, in combination with the data by Herguera et al. [2010], are now used to refine the water mass geometry in the eastern tropical North Pacific (ETNP), off Baja California, during the LGM.

The oxygen isotopic profiles for the Holocene and LGM show a similar trend that rapidly increase toward heavier isotopic values at depth, as the water column temperature decreases (Figure 6a). When the oxygen isotopic profile of the LGM is corrected by subtracting the $+1.0 \%$ o value used to correct for ice-cap growth [Schrag and De Paolo, 1993; Matsumoto et al., 2001], the oxygen isotopic gradient is $\sim 0.11 \pm 0.02 \%$ o in the 2000 to $1000 \mathrm{~m}$ depth range between the Holocene and the LGM (Figure 6a). This translates into a glacial ocean having a temperature colder than nowadays by $\sim 0.5^{\circ} \mathrm{C}$, if any, in the depth range of 2000 to $1000 \mathrm{~m}$ if only temperature accounted for such a change, which contrasts with a surface ocean during the LGM that was likely approximately $4^{\circ} \mathrm{C}$ colder than during the Holocene in this region [Herbert et al., 2001]. It indicates that the temperature and/or salinity (i.e., seawater $\delta^{18} \mathrm{O}$ ) along the Eastern Pacific have not changed significantly in the 2000 to $1000 \mathrm{~m}$ depth range within the water column, regardless the fact that the glacial North Pacific above $1000 \mathrm{~m}$ depth consisted of a water mass that was colder. 

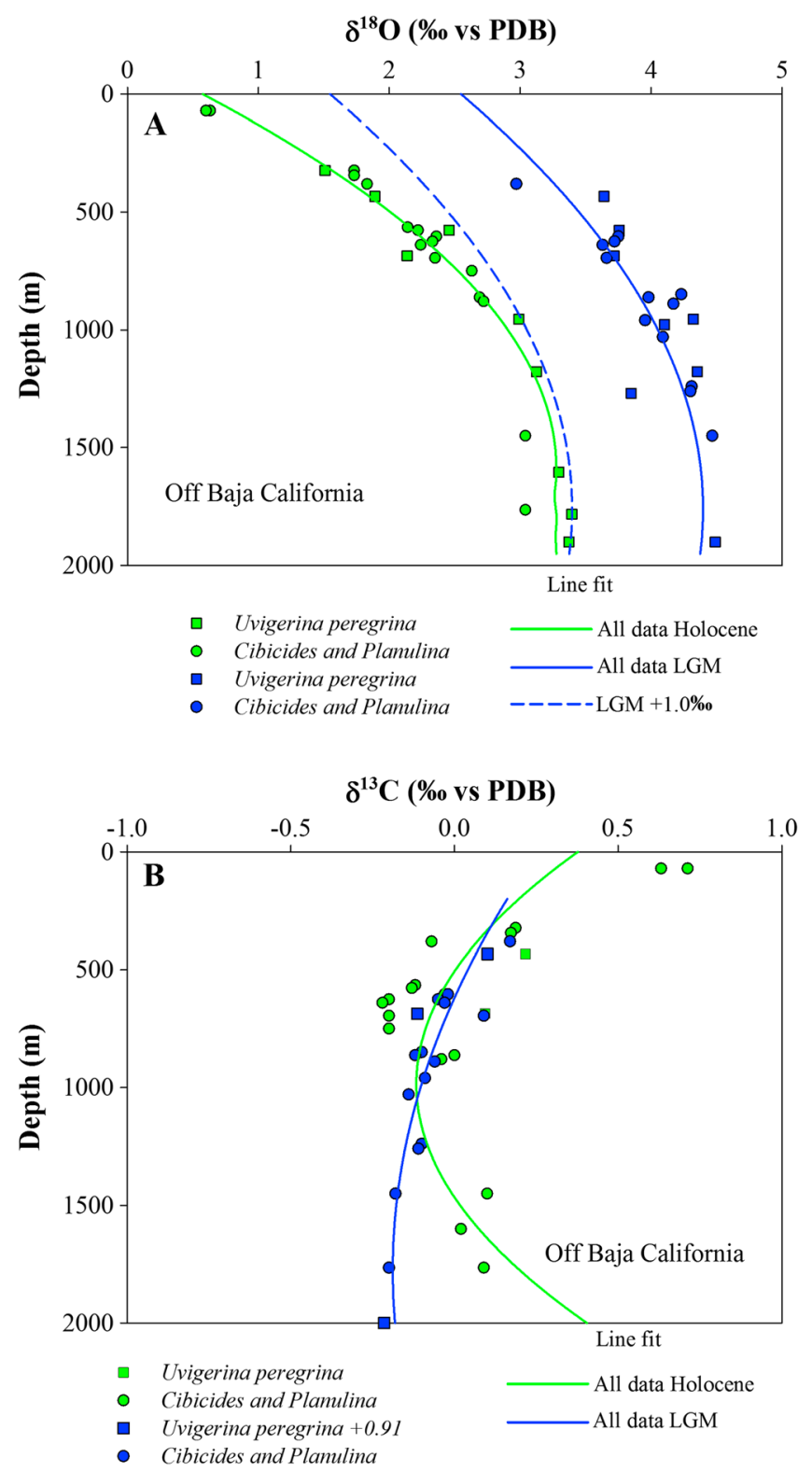

Figure 6. (a) Parameter $\delta^{18} \mathrm{O}$ of benthic forams as a function of depth during the Holocene (U. peregrina, green square, corrected; Cibicides spp., and Planulina spp., green circle) and the LGM (U. peregrina, blue square, corrected; Cibicides spp., and Planulina spp, blue circle) for the northeast Pacific (California and Baja California Margins). LGM $\delta^{18} \mathrm{O}$ of foraminifera is also shown with a correction of $-1.0 \%$ o due to the effect of polar ice growth during the Last Glacial (dashed blue line). (b) Parameter $\delta^{13} \mathrm{C}$ of benthic forams as a function of depth during the Holocene (U. peregrina, corrected was corrected by a factor of $+0.91 \% 0)$, green square; Cibicides spp. and Planulina spp., green circle), and LGM (U. peregrina, blue square, corrected; Cibicides spp., and Planulina spp., blue circle). Line fits through the data were produced using a spline function. water column that could have occurred along the water mass path between the Magdalena Margin and the Californian Margin. Such a scenario suggests a southern origin of intermediate to deep waters along the northwestern coast of North America during the LGM at those depths, as it also probably occurred during the last deglaciation [Marchitto et al., 2007] and the interstadials of the Last Glacial Period [Hendy and Kennett, 2002].

The $\delta^{13} \mathrm{C}$ of U. peregrina, C. wuellerstorfi, C. mckannai, and Planulina sp. are shown in Figure 6b (See also Table 3). For the Holocene, their $\delta^{13} \mathrm{C}$ signatures are depleted in the depth range of 500 to $1000 \mathrm{~m}$ with respect to near-surface conditions, but slightly enriched below this depth range, reproducing the modern-day distribution of the $\delta^{13} \mathrm{C}_{\mathrm{DIC}}$ inferred from in situ modern measurements (Figure 5). For the LGM, the $\delta^{13} \mathrm{C}$ values are comparable to those recorded during the Holocene in the depth range of 1000 to $300 \mathrm{~m}$, but are depleted below $1000 \mathrm{~m}$ with respect to Holocene, as previously observed by Herguera et al. [2010].

\subsection{The $\delta^{13} \mathrm{C}$ Profiles From Northeastern Pacific During the LGM} Similarly to the Magdalena Margin, the Holocene $\delta^{13} \mathrm{C}$ profiles display a very different pattern relative those observed during the LGM (Figure 7). As compared to the Magdalena Margin the 2000 to $1000 \mathrm{~m}$ depth range at the Californian sites (shown in Figure 2) points to LGM $\delta^{13} \mathrm{C}$ values lower by about $0.2 \%$ (Figure 7). This difference suggests that the Californian Margin was systematically bathed in waters with lower $\delta^{13} \mathrm{C}$ values than the Baja California Margin at this depth during the LGM, probably reflecting less ventilated waters along the California Margin and/or higher organic matter remineralization.

The new data of this study, in conjunction with data available from Herguera et al. [2010], allow us for the first time discussing the existence of a significant isotopic difference of about $0.2 \%$ between these two regions in the 1000-2000 $\mathrm{m}$ water depth range during the LGM. One explanation for the observed LGM $\delta^{13} \mathrm{C}$ gradient involves organic matter remineralization in the 


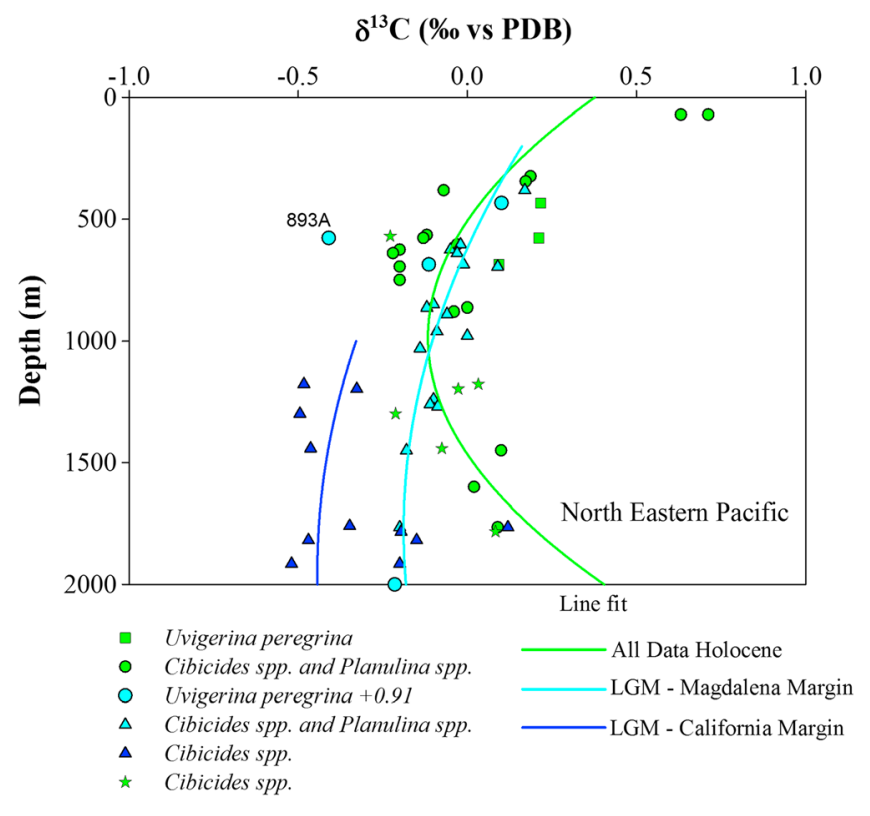

Figure 7. Parameter $\delta^{13} \mathrm{C}$ of benthic forams in the Holocene (green symbols) and LGM (blue symbols) as a function of depth from several regions of the northeast Pacific (California and Baja California Margins). Holocene: U. peregrina, green square, corrected (+0.91\%o); Cibicides spp. and Planulina spp., green circle from Baja California Margin, and Cibicides spp., green star from California Margin. LGM: U. peregrina, blue circle, corrected; Cibicides spp. and Planulina spp., blue triangle from Baja California Margin, and Cibicides spp., dark blue triangle from California Margin. Lines fits through the data were produced using a spline function. Antarctic origin during the Last Glacial Period interstadials [Hendy and Kennett, 2002]. In parallel, Lund et al. [2011] showed that ventilation ages in the deep northeastern Pacific during the LGM were similar to today, so that the tropical thermocline ventilation pathways may not involve the flushing of a deep North Pacific reservoir of dead carbon. Regardless the origin of the radiocarbon-depleted excursions recorded during the deglaciation at equatorial and northeastern tropical sites in the intermediate-depth Pacific Ocean, it remains plausible that a water mass originating from the south was responsible for the $\delta^{13} \mathrm{C}$ gradient between both regions at intermediate depth.

\subsection{The $\delta^{13}$ C Comparisons Across the Pacific Ocean: LGM}

The $\delta^{13} \mathrm{C}$ profiles above $2000 \mathrm{~m}$ during the LGM reveal regional isotopic gradients, potentially signaling different origins and water pathways (Figure 8). Regional differences depict $\delta^{13} \mathrm{C}$ signatures implying that the upper $2000 \mathrm{~m}$ waters of the northeast Pacific were more enriched in nutrients during the LGM relative to the northwest and southeast Pacific (Figure 8). Below $2000 \mathrm{~m}$, the $\delta^{13} \mathrm{C}$ profiles converge toward more negative values that at intermediate depth, pointing to more homogenous $\delta^{13} \mathrm{C}$ of Pacific Deep Waters and the existence of a deep nutricline (Figure 8).

Although it has been generally accepted that the $\delta^{13} \mathrm{C}$ distribution is primarily controlled by the biological cycling of ${ }^{13} \mathrm{C}$-depleted organic matter [Kroopnick, 1985], the effect of ocean-atmosphere $\mathrm{CO}_{2}$ exchange on the oceanic $\delta^{13} \mathrm{C}$ and its influence at the sites of deep and intermediate water formation should also be considered [Broecker and Maier-Reimer, 1992; Lynch-Stieglitz et al., 1995]. The $\delta^{13} \mathrm{C}$ was calculated using the relationship between $\delta^{13} \mathrm{C}$ and $\mathrm{PO}_{4}$ [Lynch-Stieglitz et al., 1995] using measured $\delta^{13} \mathrm{C}$ and $\mathrm{PO}_{4}$ values from the nearest GEOSECS station $\left(17^{\circ} \mathrm{N}, 123^{\circ} \mathrm{W}\right)$ and the $\delta^{13} \mathrm{C}$ determined from all species used in this study. Additionally, on the basis of the $\delta^{18} \mathrm{O}$ profiles we estimate that the contribution of thermodynamic effect on the gradient of $\delta^{13} \mathrm{C}$ observed in this study, considering a change of $0.1 \% 0 /{ }^{\circ} \mathrm{C}$ for complete isotopic air-sea equilibration [Mook et al., 1974]. In both approaches the contribution was less than $0.1 \pm 0.05 \%$, which is very similar to that reported by Herguera et al. [2010]. 


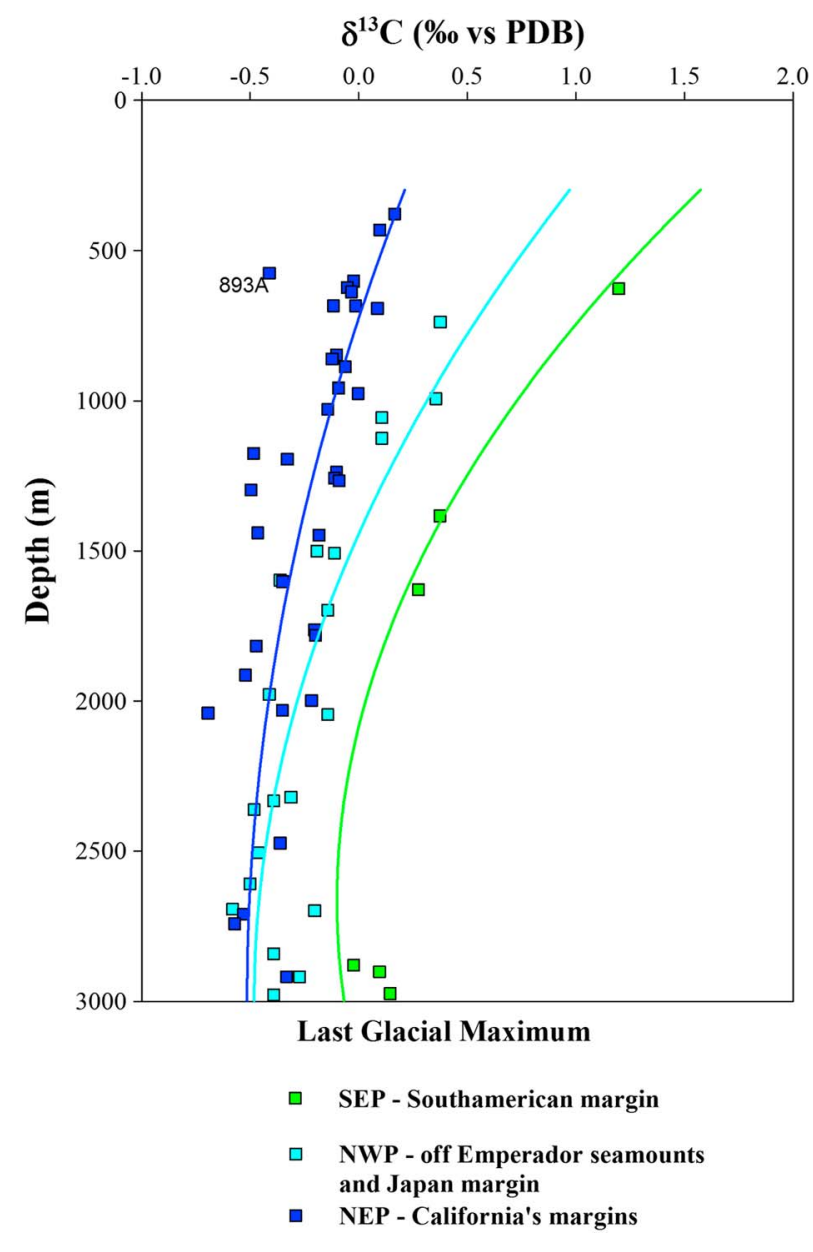

Figure 8. Carbon isotopic composition of benthic foraminifers Cibicidoides and $U$. peregrina (corrected) for the LGM in three different regions from the Pacific Ocean: SEP (southeast Pacific, green line [Mix et al., 1991; Matsumoto and Lynch-Stiegliz, 1999; Leduc et al., 2010]), NWP (northwest Pacific; light blue line [Keigwin, 1998;

Matsumoto et al., 2002]), and NEP (Northeast Pacific; blue line; data

from this study and from California compiled from others in Table 3). Lines fits through the data were produced using a spline function.
Hence, the thermodynamic effect is not driving the observed changes, although changes in air-sea fluxes of $\mathrm{CO}_{2}$ may theoretically have altered the $\delta^{13} \mathrm{C}$ of some of the sites where intermediate water formation takes place.

Another aspect to consider in the interpretation of the $\delta^{13} \mathrm{C}$ of benthic foraminifera is that it can also be affected by changes in primary productivity, as has been documented by the organic carbon oxidation rates of modern sediments [Zahn et al., 1986; McCorkle et al., 1990, 1997; Stott et al., 2000; Berelson and Stott, 2003]. Several studies using different proxies suggest that the primary productivity in the NEP was decreased during the LGM as compared to nowadays. For example, several sites off Mazatlan indicate that the organic carbon (Corg) and biogenic opal (BSi) flux to the seafloor were greatly reduced during the LGM [Ganeshram and Pedersen, 1998]. Further to the north, the California Margin ODP 1017 site suggests that lower primary productivity occurred during the LGM on the basis on organic carbon content and nitrogen isotopes, while opal sedimentary content remained at comparable levels [Hendy et al., 2004].

Finally, along the Magdalena Margin, Ortiz et al. [2004] and Blanchet et al. [2007] observed a twofold decrease in organic carbon content during the LGM as compared to Holocene levels which they attribute to decreased productivity during the LGM, while Cartapanis et al. [2014] find a slightly reduced opal flux to the seafloor during the LGM. More recently, Sánchez and Carriquiry [2007] and Carriquiry and Sanchez [2014a] reported Corg and BSi fluxes (mg/cm2/ka) for the Holocene (Corg: $802 \pm 147$ and BSi: $1480 \pm 297$ ) and the LGM (Corg: $737 \pm 92$ and BSi: 2079 \pm 348 ) in the Magdalena Margin, concluding that there were not significant differences between both periods in the accumulation of both proxies. This last estimation of nonsignificant changes of primary productivity is similar to the finding of Dean et al. [2006], who reconstructed Mo and Cd accumulation along the NE Pacific margin and concluded that there were no significant differences in productivity between both periods.

All these evidences suggest that the California and Baja California Margins may have either maintained similar productivity levels or increased primary productivity as the LGM progressed into the Holocene. Taken together, the impact of changes in primary productivity since the LGM on the water column $\delta^{13} \mathrm{C}$ and/or the pore water $\delta^{13} \mathrm{C}$ gradient, if any, may have led to an underestimation of the temporal $\delta^{13} \mathrm{C}$ changes that we describe along the NEP margin since we mainly observe more negative $\delta^{13} \mathrm{C}$ signatures during the LGM as compared to the Holocene. Hence, we believe that the changes in $\delta^{13} \mathrm{C}$ are indicative of changes in the distribution of different water masses with contrasting levels of nutrient concentration. 
The existence of a nutricline above $1500 \mathrm{~m}$ depth during the LGM, identified by the $\delta^{13} \mathrm{C}$ in benthic foraminifera, seems to be a common feature of the Pacific Ocean as it is observed in the NEP, the NWP, and the SEP (Figure 8). Evidences supporting this observation originate either from the distant North Pacific [Keigwin, 1998], from the vicinity of Japan [Matsumoto et al., 2001], from southeastern Pacific [Mix et al., 1991; Leduc et al., 2010], and from the ETNP (this work) as well as from previous data sets published in Matsumoto et al. [2002] and Herguera et al. [2010]. The spatial patterns envisioned in the computation of NEP, NWP, and SEP, however, indicate that the intermediate-depth nutricline was steeper in the SEP and the NWP than in the NEP, with lowest $\delta^{13} \mathrm{C}$ found below those depths (Figure 8). This distribution differs from that of the modern distribution of nutrients for the Pacific Ocean, where a $\delta^{13} C_{D I C}$ minimum is presently found at shallower depth [Kroopnick, 1985] (Figure 1).

McCave et al. [2008] reconstructed a hydrographic profile in the southwestern Pacific (SWP), the entrance path of several water masses into the Pacific Ocean. They found a sharp nutricline between $1500 \mathrm{~m}$ and $2000 \mathrm{~m}$ water depth separating a deep nutrient-rich water mass from a shallower nutrient-poor water mass, the former probably being inherited from circumpolar deep waters with signatures decreasing from the South Atlantic to the SWP sector [Curry and Oppo, 2005; Rosenthal et al., 1997]. Interestingly, the signatures below $2000 \mathrm{~m}$ in the SWP are among the most negative in the deep ocean, with values more negative than those found in the deep North Pacific [McCave et al., 2008; Matsumoto et al., 2002]. Whatever the deepwater path below $2000 \mathrm{~m}$ is, the less negative signatures found in the NEP cores imply mixing with another water mass that was nutrient depleted (isotopically light) as compared to the one entering the Pacific around New Zealand.

Within the main intermediate-depth nutricline, i.e., above $1500 \mathrm{~m}$ water depth, the situation in the Pacific is reversed. The lowest $\delta^{13} \mathrm{C}$ signatures are found in the NEP, with SEP and NWP being nutrient depleted (Figure 8). The $\delta^{13} \mathrm{C}$ profile of the SEP (southeastern Pacific) margin was more positive relative to the other sites in the Pacific Ocean during the LGM, suggesting that a water mass poor in nutrients was present along the South American Margin (Figure 8), as McCave et al. [2008] also documented in the SWP. Although the limited amount of data available at this depth range limits our interpretation, the general trend of the $\delta^{13} \mathrm{C}$ profile suggests that the carbon isotopic composition of the SEP at intermediate depths corresponds to the characteristics seen in the SWP that McCave et al. [2008] defined as Glacial Antarctic Intermediate Water (AAIW). When the $\delta^{13} \mathrm{C}$ profiles of the NWP and NEP are compared with that of the SEP, the isotopic profile of the NWP has characteristics more similar to the SEP profile to that of the NEP, suggesting that during the LGM the Glacial AAIW penetrated into the North Pacific and its signature eroded along its path toward the NEP, as has been suggested by several authors [e.g., McCave et al., 2008; Stott et al., 2009]. This suggests that circulation at intermediate depths kept an asymmetric distribution relative to the rest of the Pacific Ocean where an old water mass, more respired and probably with a larger concentration of nutrients, was present at intermediate depths in the NEP.

\subsection{Implications for Glacial Ocean Circulation}

The inferred low-nutrient condition of the glacial upper northwest Pacific implies that changes in the mode and/or volume of intermediate water formation occurred in the North Pacific [Keigwin, 1998] and/or the Southern Ocean [Sigman and Boyle, 2000]. Adkins et al. [2002] found that the deep glacial water in the Pacific and Southern Oceans were characterized by colder and much saltier water mass formed in the Antarctic region, which probably favored the development of a glacial front that separated the warmer and less salty intermediate waters from the Southern Ocean deep waters. The deep Southern Ocean during the LGM was characterized by very low $\delta^{13} \mathrm{C}$ values that increased to the north in both the Atlantic and Indo-Pacific [Curry et al., 1988], suggesting that a gradual mixing of bottom and deep waters with waters above $\sim 2000 \mathrm{~m}$ was occurring. A steep nutricline during the LGM was also confined to the northern Indian Ocean [Kallel et al., 1988]. A deep nutricline hence seems to be a common feature in the world ocean during the LGM.

In the Southern Ocean, it has been hypothesized that during the LGM there was a reduction in deep water upwelling into the Antarctic surface possibly due to an equatorward shift in the belt of eastward winds and/or a freshening of the surface due to an increase in sea ice formation [Sigman and Boyle, 2000; Adkins et al., 2002]. Modeling studies indicate that increased winds in the sub-Antartic region during the LGM could have produced upwelling of intermediate waters initially formed in the Atlantic and North Pacific and lead to the formation of North Pacific Deep Waters that may explain why the SW Pacific Deep Waters remained more 
nutrient-rich than their NEP and NWP counterparts [Toggweiler et al., 2006]. Increased iron deposition from settling dust was also larger during the Last Glacial Maximum [see, e.g., Lamy et al., 2014], resulting in increased nutrient utilization in the sub-Antarctic sector and in reduced nutrient transport to low latitudes via AAIW and Subantarctic Mode Waters. The hypothesized model proposes decreased nutrients and enriched $\delta^{13} \mathrm{C}$ in the upper $1500 \mathrm{~m}$ of the world ocean, as supported here by the $\delta^{13} \mathrm{C}$ of benthic foraminifera from the North Pacific where lowest $\delta^{13} \mathrm{C}$ remained confined to the NEP, probably reflecting the terminus of middepth water circulation during the LGM as we observe nowadays (Figure 8).

\section{Conclusions}

1. Where epibenthic foraminifera species are rare, such as in the $O M Z$ of the eastern tropical North Pacific, our results show that shallow endobenthic foraminifera may allow, albeit with some caution, to reconstruct $\delta^{13} \mathrm{C}$ of water masses.

2. The comparison of Holocene and LGM $\delta^{18} \mathrm{O}$ profiles along the Magdalena Margin suggests that temperature and/or salinity did not change significantly between the Holocene and the LGM between 2000 and $500 \mathrm{~m}$ water depth.

3. The comparison of Holocene and $\mathrm{LGM} \delta^{13} \mathrm{C}$ profiles along the Magdalena Margin indicates that a nutricline existed above $1500 \mathrm{~m}$ with relatively homogenous values at deeper depth, which differs from the Holocene values where a $\delta^{13} \mathrm{C}$ minimum is clearly centered between 500 and $1000 \mathrm{~m}$ water depth.

4. The comparison of the Magdalena Margin and the California Margin $\delta^{13} \mathrm{C}$ profiles for the LGM suggests regional contrasts in the $\delta^{13} \mathrm{C}$ at intermediate depth, with more negative values being found along the California Margin. This suggests a larger influence of AAIW and Subantarctic Mode Waters in the eastern tropical North Pacific.

5. A broader comparison of the $\delta^{13} \mathrm{C}$ values of the NEP with those from the NWP and SEP further suggests that the NEP remained the most ${ }^{13} \mathrm{C}$-depleted waters at intermediate depths in the Pacific, with waters flowing along the California Margin likely being situated close to the terminus of the LGM intermediate waters.

\section{Acknowledgments}

Excellent support was provided throughout this expedition by Captain Chris Curl and his crew and by members of the technical staff from Scripps Institution of Oceanography, Oregon State University, and Lamont-Doherty Earth Observatory. We thank Julio Villaescusa and Pedro Castro for their excellent laboratory support and help throughout the study. This work was supported by Mexico's CONACyT and by financial and logistic support from the Universidad Autónoma de Baja California to J.D.C., by USA-NSF grants OCE-9809026 to Alexander van Geen (Lamont-Doherty Earth Observatory), and by SIP-IPN grants to A.S. (Instituto Politecnico Nacional). We also greatly thank Tom Marchitto and Joe Ortiz for their kind support, feedback, and suggestions made in a previous version of this manuscript. The new data presented in this paper will be available for public use at the NOAA National Climatic Data Center (http://www.ncdc. noaa.gov/data-access/paleoclimatologydata/datasets/paleoceanography).

\section{References}

Adkins, J. F., K. McIntyre, and D. P. Schrag (2002), The salinity, temperature and $\delta^{18} \mathrm{O}$ of the glacial deep ocean, Science, 298, $1769-1773$. Anderson, P. A., C. D. Charles, and W. H. Berger (2001), Walvis Paradox confirmed for the early Quaternary at the southern end of the Namibia upwelling system, ODP Site 1085, in Proc. ODP, Sci. Results, vol. 175, edited by G. Wefer, W. H. Berger, and C. Richter, pp. 1-31.

Andreasen, D., M. Flower, M. Harvey, S. Chang, and A. C. Ravelo (2000), Data Report: Late Pleistocene oxygen and carbon isotopic records from Sites 1011, 1012, and 1018, in Proceedings of the Ocean Drilling Program, Sci. Results, vol. 167, edited by M. Lyle et al., pp. 141-144, Ocean Drilling Program, College Station, Tex., doi:10.2973/odp.proc.sr.167.225.2000.

Belanger, P. E., W. B. Curry, and R. K. Mathews (1981), Core-top evaluation of benthic foraminiferal isotopic ratios for paleo-oceanographic interpretations, Palaeogeogr. Palaeoclimatol. Palaeoecol., 33, 205-220.

Bemis, B. E., H. J. Spero, J. Bijma, and D. W. Lea (1998), Reevaluation of the oxygen isotopic composition of planktonic foraminifera: Experimental results and revised paleotemperature equations, Paleoceanography, 13, 150-160, doi:10.1029/98PA00070.

Berelson, W. and L. D. Stott (2003), Productivity and organic carbon rain to the California Margin sea floor: Modern and paleoceanographic perspectives, Paleoceanography 18(1), 1002, doi:10.1029/2001PA000672.

Bickert, T., and A. Mackensen (2004), Last Glacial to Holocene changes in South Atlantic deep water circulation, in The South Atlantic in the Late Quaternary: Reconstruction of Material Budget and Current Systems, edited by G. Wefer, S. Mulitza, and V. Rathmeyer, pp. 671-693, Springer, Berlin.

Blanchet, C., N. Thouveny, L. Vidal, G. Leduc, K. Tachikawa, E. Bard, and L. Beaufort (2007), Terrigenous input response to glacial/interglacial climatic variations over South Baja California: A rock magnetic approach, Quat. Sci. Rev., 26, 3118-3133.

Broecker, W. S. (2009), The mysterious ${ }^{14} \mathrm{C}$ decline, Radiocarbon, 51, 109-119.

Broecker, W. S., and E. Maier-Reimer (1992), The influence of air and sea exchange on the carbon isotope distribution in the sea, Global Biogeochem. Cycles, 6, 315-320, doi:10.1029/92GB01672.

Broecker, W. S., and T. S. Peng (1982), Tracers in the Sea, 690 pp., LDGO Press, Lamont-Doherty Geological Observatory, Columbia Univ., Palisades, N. Y. Bustos-Serrano, H., and R. Castro-Valdez (2006), Flux of nutrients in the Gulf of California: Geostrophic flow, Mar. Chem., 99, $210-219$.

Carriquiry, J. D., and A. Sanchez (2014a), Ópalo biogénico sedimentario en el extremo Sur del sistema de surgencias de la Corriente de California: Etapas isotópicas marinas 1-5, in Dinámica del Ecosistema Pelágico frente a Baja California: 1997-2007, edited by G. Gaxiola-Castro and R. Durazo, pp. 227-238, Instituto Nacional de Ecología, México, D. F.

Carriquiry, J. D., and A. Sanchez (2014b), A. Productivity changes at the Magdalena Margin, SW Baja California peninsula, during the last 50,000 years, in Synthesis Series: Environmental Status Of The Ecosystems Of Northwestern Mexico, edited by E. V. Wehncke et al., pp. 1-19, UC-MEXUS, SEMARNAT and INECC, Mexico City.

Cartapanis, O., K. Tachikawa, and E. Bard (2011), Northeastern Pacific oxygen minimum zone variability over the past 70 kyr: Impact of biological production and oceanic ventilation, Paleoceanography, 26, PA4208, doi:10.1029/2011PA002126.

Cartapanis, O., K. Tachikawa, O. E. Romero, and E. Bard (2014), Persistent millennial-scale link between Greenland climate and northern Pacific oxygen minimum zone under interglacial conditions, Clim. Past, 10, 405-418, doi:10.5194/cp-10-405-2014.

Corliss, B. H., D. C. McCorkle, and D. M. Higdon (2002), A time series study of the carbon isotopic composition of deep-sea benthic foraminifera, Paleoceanography, 17(3), 1036, doi:10.1029/2001PA000664. 
Curry, W. B., and D. W. Oppo (2005), Glacial water mass geometry and the distribution of $\delta^{13} \mathrm{Cof}_{\Sigma \mathrm{CO}_{2}}$ in the western Atlantic Ocean, Paleoceanography, 20, PA1017, doi:10.1029/2004PA001021.

Curry, W. B., J. C. Duplessy, L. D. Labeyrie, and N. J. Shackleton (1988), Changes in the distribution of $\delta^{13} \mathrm{C}$ of deep water $\mathrm{SCO}_{2}$ between the Last Glaciation and the Holocene, Paleoceanography, 3, 317-341, doi:10.1029/PA003i003p00317.

Dean, W. E., Y. Zheng, J. D. Ortiz, and A. van Geen (2006), Sediment Cd and Mo accumulation in the oxygen-minimum zone off western Baja California linked to global climate over the past 52 kyr, Paleoceanography, 21, PA4209, doi:10.1029/2005PA001239.

De Pol-Holz, R., L. Keigwin, and J. Southon (2010), D. Hebbeln and M. Mohtadi (2010), No signature of abyssal carbon in intermediate waters off Chile during deglaciation, Nat. Geosci., 3, 192-195, doi:10.1038/ngeo745.

Denton, G. H., W. S. Broecker, and R. B. Alley (2006), The mystery interval 17.5 to 14.5 kyrs ago, Pages News, 14, 14-16.

Duplessy, J. C., N. J. Shackleton, K. Matthews, W. Prell, W. F. Ruddiman, M. Caralp, and C. H. Hendy (1984), ${ }^{13} \mathrm{C}$ record of benthic foraminifera in the last interglacial ocean: Implications for the cycle carbon and the global deep water circulation, Quat. Res., 21, 225-243.

Duplessy, J. C., N. J. Shackleton, R. G. Fairbanks, L. Labeyrie, D. Oppo, and N. Kallel (1988), Deepwater source variations during the last climatic cycle and their impact on the global deepwater circulation, Paleoceanography, 3, 343-360, doi:10.1029/PA003i003p00343.

Emile-Geay, J., M. A. Cane, R. Seager, A. Kaplan, and P. Almasi (2007), El Niño as a mediator of the solar influence on climate, Paleoceanography, 22, PA3210, doi:10.1029/2006PA001304.

Epstein, S., R. Buchsbaum, H. A. Lowenstam, and H. C. Urey (1953), Revised carbonate-water isotopic temperature scale, Geol. Soc. Am. Bull., $64,1315-1325$

Fontanier, C., F. Jorissen, L. Licari, A. Alexandre, P. Anschutz, and P. Carbonel (2002), Live benthic foraminiferal faunas from bay Biscay: Faunal density, composition, and microhabitats, Deep Sea Res., 49, 751-785, doi:10.1016/S0967-0637(01)00078-4.

Fontanier, C. A., F. J. Mackensen, P. Jorissen, L. L. Anschutz, and C. Griveaud (2006), Stable oxygen and carbon isotopes of live benthic foraminifera from the Bay of Biscay: Microhabitat impact and seasonal variability, Mar. Micropaleontol., 58, 159-183.

Galbraith, E. D., S. L. Jaccard, T. F. Pedersen, D. M. Sigman, G. H. Haug, M. Cook, J. Southon, and R. Francois (2007), Carbon dioxide release from the North Pacific abyss during the last deglaciation, Nature, 449, 890-893.

Ganeshram, R. J., and T. F. Pedersen (1998), Glacial-interglacial variability in upwelling and bioproductivity off NW Mexico: Implications for Quaternary paleoclimate, Paleoceanography, 13, 634-645, doi:10.1029/98PA02508.

Geslin, E., P. Heinz, F. Jorissen, and C. Hemleben (2004), Migratory response of deep-sea benthic foraminifera to variable oxygen conditions: Laboratory investigations, Mar. Micropaleontol., 54, 227-243.

Graham, D. W., B. H. Corliss, M. L. Bender, and L. D. Keigwin (1981), Carbon and oxygen isotopic disequilibria of recent deep-sea benthic foraminifera, Mar. Micropaleontol., 6, 483-497.

Hain, M. P., D. M. Sigman, and G. H. Haug (2014), Distinct roles of the Southern Ocean and North Atlantic in the deglacial atmospheric radiocarbon decline, Earth Planet. Sci. Lett., 394, 198-208.

Hall, I. R., I. N. McCave, N. J. Shackleton, G. P. Weedon, and S. E. Harris (2001), Intensified deep Pacific inflow and ventilation in Pleistocene glacial time, Nature, 412, 809-812.

Helly, J. J., and L. A. Levin (2004), Global distribution of naturally occurring marine hypoxia on continental margins, Deep Sea Res., Part I, 51 , 1159-1168.

Hendy, I., and J. P. Kennett (2002), Tropical forcing of North Pacific Intermediate Water distribution during Late Quaternary rapid climate change?, Quat. Sci. Rev., 22, 673-689.

Hendy, I. L., T. F. Pedersen, J. P. Kennett, and R. Tada (2004), Intermittent existence of a Southern Californian upwelling cell during submillennial climate change of the last $60 \mathrm{kyr}$, Paleoceanography, 19, PA3007, doi:10.1029/2003PA000965.

Herbert, T. D., J. D. Schuffert, D. Andreasen, L. Heusser, M. Lyle, A. Mix, A. C. Ravelo, L. D. Stott, and J. C. Herguera (2001), Collapse of the California Current during glacial maxima. Linked to climate change on land, Science, 293, 71-76.

Herguera, J. C., E. Jansen, and W. H. Berger (1992), Evidence for a bathyal front at $2000 \mathrm{~m}$ in the glacial Pacific, based on a depth transect on Ontong Java Plateau, Paleoceanography, 7, 79-117, doi:10.1029/92PA00869.

Herguera, J. C., T. Herbert, M. Kashgarian, and C. Charles (2010), Intermediate and deep water mass distribution in the Pacific during the Last Glacial Maximum inferred from oxygen and carbon stable isotopes, Quater. Sci. Rev., 29, 1228-1245.

Hill, T. M., J. P. Kennett, D. K. Pak, R. J. Behl, C. Robert, and L. Beaufort (2006), Pre-Bolling warming in Santa Barbara Basin, California: Surface and intermediate water records of early deglacial warmth, Quat. Sci. Rev., 25, 2835-2845, doi:10.1016/j.quascirev.2006.03.012.

Hut, G. (1987), Consultant's Group Meeting on Stable Isotope Reference Samples for Geochemical and Hydrological Investigations, $42 \mathrm{pp}$. International Atomic Energy Agency, Vienna.

Jaccard, S. L., and E. D. Galbraith (2012), Large climate-driven changes of oceanic oxygen concentrations during the last deglaciation, Nat. Geosci., 5, 151-156.

Jaccard, S. L., and E. D. Galbraith (2013), Direct ventilation of the North Pacific did not reach the deep ocean during the last deglaciation, Geophys. Res. Lett., 40, 1-5, doi:10.1029/2012GL054118.

Jorissen, F. J., H. C. de Stigter, and J. G. V. Widmark (1995), A conceptual model explaining benthic foraminiferal microhabitats, Mar. Micropaleontol., 26, 3-15.

Kallel, N., L. D. Labeyrie, A. Juillet-Leclerc, and J.-C. Duplessy (1988), A deep hydrological front between intermediate and deep-water masses in the Glacial Indian Ocean, Nature, 333, 651-655.

Katz, M. E., D. R. Katz, J. D. Wright, K. G. Miller, D. K. Pak, N. J. Shackleton, and E. Thomas (2003), Early Cenozoic benthic foraminiferal isotopes: Species reliability and interspecies correction factors. Paleoceanography 18(2), 1024, doi:10.1029/2002PA000798.

Keigwin, L. D. (1987), North Pacific deep water formation during the latest glaciation, Nature, 330, 362-364.

Keigwin, L. D. (1998), Glacial-age hydrography of the far northwest Pacific Ocean, Paleoceanography, 13, 323-339, doi:10.1029/ 98PA00874.

Keigwin, L. D. (2002), Late Pleistocene-Holocene paleoceanography and ventilation of the Gulf of California, J. Oceanogr., 58, 421-432.

Kennett, J. P., and B. L. Ingram (1995), A 20,000 year record of ocean circulation and climatic change from the Santa Barbara Basin, Nature, $377,510-514$

Kennett, J. P., K. G. Cannariato, I. L. Hendy, and R. J. Behl (2000), Carbon isotopic evidence for methane hydrate instability during Quaternary interstadials, Science, 288, 128-133.

Kim, S. T., and J. R. O'Niel (1997), Equilibrium and non-equilibrium oxygen isotope effects in synthetic carbonates, Geochim. Cosmochim. Acta, $61,3461-3475$

Kroopnick, P. (1985), The distribution of ${ }^{13} \mathrm{C}_{\text {of }} \mathrm{CO}_{2}$ in the world ocean, Deep Sea Res., Part I, 32, $57-84$.

Kwiek, P., and A. C. Ravelo (1999), Pacific Ocean intermediate and deep water circulation during the Pliocene, Palaeogeogr. Palaeoclimatol. Palaeoecol., 154, 191-217. 
Lamy, F., R. Gersonde, G. Winckler, O. Esper, A. Jaeschke, G. Kuhn, J. Ullermann, A. Martínez-Garcia, F. Lambert, and R. Kilian (2014), Increased dust deposition in the Pacific Southern Ocean during glacial periods, Science, 343, 403-407.

Leduc, G., L. Vidal, K. Tachikawa, F. Rostek, C. Sonzogni, L. Beaufort, and E. Bard (2007), Moisture transport across Central America as a positive feedback on abrupt climatic changes, Nature, 445, 908-911.

Leduc, G., L. Vidal, K. Tachikawa, and E. Bard (2010), Changes in eastern Pacific Ocean ventilation at intermediate depth over the last 150 kyr BP, Earth Planet. Sci. Lett., 298, 217-228.

Levitus, S., and Y. Boyer (1994), World Ocean Atlas 1994, Volume 4: Temperature, 117 pp., Natl. Oceanogr. Data Cent., U.S. Gov. Print. Off., Washington, D. C.

Levitus, S., R. Burgett, and T. Boyer (1994), World Ocean Atlas 1994, Vol. 3: Salinity. NOAA Atlas NESDIS 3, 99 pp., U.S. Gov. Print. Off., Washington, D. C.

Loubere, P., P. Meyers, and A. Gary (1995), Benthic foraminiferal microhabitat selection, carbon isotope values, and association with larger animals: A test with Uvigerina peregrina, J. Foraminiferal Res., 25, 83-95.

Lund, D. C., and A. Mix (1998), Millennial-scale deep water oscillations: Reflections of the North-Atlantic in the deep Pacific from 10 to 60 ka, Paleoceanography, 13, 10-19, doi:10.1029/97PA02984.

Lund, D. C., A. Mix, and J. Southon (2011), Increased ventilation age of the deep northeast Pacific Ocean during the last deglaciation, Nat. Geosci., 4, 771-774, doi:10.1038/ngeo1272.

Lynch-Stieglitz, J., and R. G. Fairbanks (1994), A conservative tracer for glacial ocean circulation from carbon isotope and palaeo-nutrient measurements in benthic foraminifera, Nature, 369, 308-310.

Lynch-Stieglitz, J., T. F. Stocker, W. S. Broecker, and R. G. Fairbanks (1995), The influence of air-sea exchange on the isotopic composition of oceanic carbon: Observations and modeling, Global Biogeochem. Cycles, 9, 653-665, doi:10.1029/95GB02574.

Mackensen, A., H.-W. Hubberten, T. Bickert, G. Fischer, and D. K. Fütterer (1993), The $\delta^{13} \mathrm{C}$ in benthic foraminiferal tests of Fontbotia wuellerstorfi (Schwager) relative to $\delta^{13} \mathrm{C}$ of dissolved inorganic carbon in Southern Ocean deep water: Implications for glacial ocean circulation models, Paleoceanography, 8(5), 587-610, doi:10.1029/93PA01291.

Mackensen, A., M. Rudolph, and G. Kuhn (2001), Late Pleistocene deep-water circulation in the subantarctic eastern Atlantic, Global Planet. Change, 30(3), 197-229.

Marchitto, T. M., S. J. Lehman, J. D. Ortiz, J. Flückiger, and A. van Geen (2007), Marine radiocarbon evidence for the mechanism of deglacial atmospheric $\mathrm{CO}_{2}$ rise, Science, 316, 1456-1459.

Marchitto, T. M., W. B. Curry, J. Lynch-Stieglitz, S. P. Bryan, K. M. Cobb, and D. C. Lund (2014), Improved oxygen isotope temperature calibrations for cosmopolitan benthic foraminifera, Geochim. Cosmochim. Acta, 130, 1-11, doi:10.1016/j.gca.2013.12.034.

Matsumoto, K. (2007), Radiocarbon-based circulation age of the world oceans, J. Geophys. Res., 112, C09004, doi:10.1029/ $2007 J C 004095$

Matsumoto, K., and J. Lynch-Stiegliz (1999), Similar glacial and Holocene deep water circulation inferred from southeast Pacific benthic foraminiferal carbon isotope composition, Paleoceanography, 14, 146-163, doi:10.1029/1998PA900028.

Matsumoto, K., J. Lynch-Stiegliz, and R. F. Anderson (2001), Similar glacial and Holocene Southern Ocean hydrography, Paleoceanography, 16, 1-10, doi:10.1029/2000PA000549.

Matsumoto, K., T. Oba, J. Lynch-Stieglitz, and H. Yamamoto (2002), Interior hydrography and circulation on the glacial Pacific Ocean, Quat. Res., 21, 1693-1704.

McCave, I. N., L. Carter, and I. R. Hall (2008), Glacial-interglacial changes in water mass structure and flow in the SW Pacific Ocean, Quat. Sci. Rev., 27, 1886-1908.

McCorkle, D. C., S. R. Emerson, and P. D. Quay (1985), Stable carbon isotopes in marine porewaters, Earth Planet. Sci. Lett., $74,13-26$.

McCorkle, D. C., L. D. Keigwin, B. H. Corliss, and S. R. Emerson (1990), The influence of microhabitats on the carbon isotopic composition of deep-sea benthic foraminifera, Paleeoceanography, 5, 161-185.

McCorkle, D. C., B. H. Corliss, and C. Farnham (1997), Vertical distributions and isotopic compositions of live (stained) benthic foraminifera from the North Carolina and California continental margins, Deep Sea Res., Part I, 44, 983-1024.

Mix, A. C., N. G. Pisias, R. Zahn, W. Rugh, C. Lopez, and K. Nelson (1991), Carbon-13 in Pacific deep and intermediate waters, 0-370 kyr: Implications for ocean circulation and Pleistocene $\mathrm{CO}_{2}$, Paleoceanography, 6, 205-226, doi:10.1029/90PA02303.

Mook, W. G., J. C. Bommerson, and W. H. Staverman (1974), Carbon isotope fractionation between dissolved bicarbonate and gaseous carbon dioxide, Earth Planet. Sci. Lett., 22, 169-76.

Ohkushi, K., A. Suzuki, H. Kawahata, and L. P. Gupta (2003), Glacial-interglacial deep-water changes in the northwestern Pacific inferred from individual foraminiferal $\delta^{18} \mathrm{O}$ and $\delta^{13} \mathrm{C}$, Mar. Micropaleontol., 48, 281-290.

Okazaki, Y., A. Timmermann, L. Menviel, N. Harada, A. Abe-Ouchi, M. O. Chikamoto, A. Mouchet, and H. Asahi (2010), Deepwater formation in the North Pacific during the last glacial termination, Science, 329, 200-204.

Oppo, D. W., R. G. Fairbanks, A. L. Gordon, and N. J. Shackleton (1990), Late pleistocene Southern Ocean $\delta^{13}$ C variability, Paleoceanography, 5 , 43-54, doi:10.1029/PA005i001p00043.

Ortiz, J. D., S. B. O'Connell, J. DelViscio, W. Dean, J. D. Carriquiry, T. M. Marchitto, Y. Zheng, and A. van Geen (2004), Enhanced marine productivity off western North America during warm climate intervals of the past 52 k.y, Geology, 32, 521-524.

Ostermann, D. R., and W. B. Curry (2000), Calibration of stable isotopic data: An enriched delta 18-O standard used for source gas-mixing detection and correction, Paleoceanography, 15(3), 353-360.

Rae, J. W. B., M. Sarnthein, G. L. Foster, A. Ridgwell, P. M. Grootes, and T. Elliott (2014), Deep water formation in the North Pacific and deglacial $\mathrm{CO}_{2}$ rise, Paleoceanography, 29, 645-667, doi:10.1002/2013PA002570.

Reid, J. L. (1965), Intermediate Waters of the Pacific Ocean, John Hopkins Oceanogr. Stud., 85 pp., The John Hopkins Press, Baltimore.

Rosenthal, Y., E. A. Boyle, and L. Labeyrie (1997), Last Glacial Maximum paleochemistry and deepwater circulation in the Southern Ocean: Evidence from foraminiferal cadmium, Paleoceanography, 12, 787-796, doi:10.1029/97PA02508.

Sánchez, A., and J. D. Carriquiry (2007), Accumulation of Corg, Norg, Porg and BSi in Magdalena Margin, B. C. S., México during the last 26 ka, Cienc. Mar., 33, 23-35.

Schmittner, A., N. Gruber, A. C. Mix, R. M. Key, A. Tagliabue, and T. K. Westberry (2013), Biology and air-sea gas exchange controls on the distribution of carbon isotope ratios $\left(\delta^{13} \mathrm{C}\right)$ in the ocean, Biogeosciences, 10, 5793-5816, doi:10.5194/bg-10-5793-2013.

Schmitz, W. J. (1995), On the interbasin-scale thermohaline circulation, Rev. Geophys., 33, 151-173, doi:10.1029/95RG00879.

Schrag, D. P., and D. J. De Paolo (1993), Determination of $\delta{ }^{18} \mathrm{O}$ of seawater in the deep ocean during the Last Glacial Maximum, Paleoceanography, 8, 1-6, doi:10.1029/92PA02796.

Shackleton, N. J. (1974), Attainment of isotopic equilibrium between ocean water and the benthonic foraminifera genus Uvigerina; Isotopic changes in the ocean during the Last Glacial, Colloq. Int. CNRS, 219, 203-219. 
Shackleton, N. J., and N. D. Opdyke (1973), Oxygen isotope and paleomagnetic stratigraphy of equatorial Pacific core V28-238: Oxygen isotope temperature and ice volumes on a 105 year and 106 year scale, Quat. Res., 3, 39-55.

Shackleton, N. J., M. A. Hall, and E. Vincent (2000), Phase relationships between millennia-scale events 64,000-24,000 years ago, Paleoceanography, 15, 535-569, doi:10.1029/2000PA000513.

Sigman, D. M., and E. A. Boyle (2000), Glacial/interglacial variations in atmospheric carbon dioxide, Nature, 407, $859-869$.

Stott, L., and A. Timmermann (2011), Hypothesized link between glacial/interglacial atmospheric $\mathrm{CO}_{2}$ Cycles and storage/release of $\mathrm{CO}_{2}$-rich fluids from the deep sea, in Abrupt Climate Change: Mechanisms, Patterns, and Impacts, Geophys. Monogr. Ser., vol. 193, pp. 123-138, AGU, Washington, D. C.

Stott, L., J. Southon, A. Timmermann, and A. Koutavas (2009), Radiocarbon age anomaly at intermediate water depth in the Pacific Ocean during the last deglaciation, Paleoceanography, 24, PA2223, doi:10.1029/2008PA001690.

Stott, L. D., M. Neumann, and D. Hammond (1999), Intermediate water ventilation on the northeastern Pacific margin during the late Pleistocene inferred from benthic foraminiferal $\delta^{13}$ C, Paleoceanography, 15, 161-169, doi:10.1029/1999PA000375.

Stott, L. D., W. Berelson, D. Gorsline, and R. Douglas (2000), Increased dissolved oxygen in Pacific intermediate waters due to lower rates of carbon oxidation in sediments, Nature, 407, 367-370.

Tachikawa, K., and H. Elderfield (2002), Microhabitat effects on $\mathrm{Cd} / \mathrm{Ca}$ and $\mathrm{d}^{13} \mathrm{C}$ of benthic foraminifera, Earth Planet. Sci. Lett., 202, 607-624.

Talley, L. D. (1991), An Okhotsk Sea water anomaly: Implications for ventilation in the North Pacific, Deep Sea Res., Part A, 38, S171-S190.

Talley, L. D. (1993), Distribution and formation of North Pacific Intermediate Water, J. Phys. Oceanogr., 23, 517-537.

Toggweiler, J. R., J. L. Russell, and S. R. Carson (2006), Midlatitude westerlies, atmospheric $\mathrm{CO}_{2}$, and climate change during the ice ages, Paleoceanography, 21, PA2005, doi:10.1029/2005PA001154.

Tsuchiya, M. (1981), The origin of Pacific equatorial $13^{\circ} \mathrm{C}$ water, J. Phys. Oceanogr., 11, 794-812.

van Geen, A., and Scientific Party RV Melville (2001), Baja California coring cruise OXMZ01MV: Core descriptions and CTD/Rosette data: Lamont-Doherty Observatory Technical Report LDEO 2001-01.

van Geen, A., R. G. Fairbanks, P. Dartnell, M. McGann, and J. V. Gardner (1996), Ventilation changes in the northeast Pacific during the last deglaciation, Paleoceanography, 11, 519-528, doi:10.1029/96PA01860.

van Geen, A., Y. Zheng, J. M. Bernhard, K. G. Cannariato, J. D. Carriquiry, W. E. Dean, B. W. Eakins, J. D. Ortiz, and J. Pike (2003), On the preservation of laminated sediments along the western margin of North America. Paleoceanography 18(4), 1098, doi:10.1029/ 2003 PA000911.

van Geen, A., W. M. Smethie Jr., A. Horneman, and H. Lee (2006), Sensitivity of the North Pacific oxygen minimum zone to changes in ocean circulation: A simple model calibrated by chlorofluorocarbons, J. Geophys. Res., 111, C10004, doi:10.1029/2005JC00319.

Van Scoy, K. A., D. O. Olson, and R. A. Fine (1991), Ventilation of North Pacific Intermediate Waters: The role of the Alaska Gyre, J. Geophys. Res., 96, 16,801-16,810, doi:10.1029/91JC01783.

Woodruff, F., S. M. Savin, and R. G. Douglas (1980), Biological fractionation of oxygen and carbon isotopes by recent benthic foraminifera, Mar. Micropaleontol., 5, 3-11.

Wyrtki, K. (1967), Circulation and water mass in the eastern equatorial Pacific Ocean, Int. J. Oceanol. Limnol., 1, $117-147$.

Zahn, R., K. Winn, and M. Sarnthein (1986), Benthic foraminiferal $\delta^{13} \mathrm{C}$ and accumulation rates of organic carbon: Uvigerina peregrina group and Cibicidoides wuellerstorfi, Paleoceanography, 1, 27-42, doi:10.1029/PA001i001 p00027. 